\title{
Affinity, life cycle, and intracellular complexity of organic-walled microfossils from the Mesoproterozoic of Shanxi, China
}

\author{
Heda Agić ${ }^{1}$, Małgorzata Moczydłowska ${ }^{1}$, and Lei-Ming Yin $^{2}$ \\ ${ }^{1}$ Department of Earth Sciences, Palaeobiology, Uppsala University, Villavägen 16, SE 75236 Uppsala, Sweden, 〈heda.agic@ geo.uu.se〉, \\ $\langle$ malgo.vidal@pal.uu.se〉 \\ ${ }^{2}$ Nanjing Institute of Geology and Palaeontology, Chinese Academy of Sciences, 39 East Beijing Road, Nanjing 210008, China
}

\begin{abstract}
Light microscope and scanning electron microscope observations on new material of unicellular microfossils Dictyosphaera macroreticulata and Shuiyousphaeridium macroreticulatum, from the Mesoproterozoic Ruyang Group in China, provide insights into the microorganisms' biological affinity, life cycle and cellular complexity. Gigantosphaeridium fibratum n. gen. et sp., is described and is one of the largest Mesoproterozoic microfossils recorded. Phenotypic characters of vesicle ornamentation and excystment structures, properties of resistance and cell wall structure in Dictyosphaera and Shuiyousphaeridium are all diagnostic of microalgal cysts. The wide size ranges of the various morphotypes indicate growth phases compatible with the development of reproductive cysts. Conspecific biologically, each morphotype represents an asexual (resting cyst) or sexual (zygotic cyst) stage in the life cycle, respectively. We reconstruct this hypothetical life cycle and infer that the organism demonstrates a reproductive strategy of alternation of heteromorphic generations. Similarly in Gigantosphaeridium, a metabolically expensive vesicle with processes suggests its protective role as a zygotic cyst. In combination with all these characters and from the resemblance to extant green algae, we propose the placement of these ancient microorganisms in the stem group of Chloroplastida (Viridiplantae). A cell wall composed of primary and secondary layers in Dictyosphaera and Shuiyouisphaeridium required a high cellular complexity for their synthesis and the presence of an endomembrane system and the Golgi apparatus. The plastid was also present, accepting the organism was photosynthetic. The biota reveals a high degree of morphological and cell structural complexity, and provides an insight into ongoing eukaryotic evolution and the development of complex life cycles with sexual reproduction by $1200 \mathrm{Ma}$.
\end{abstract}

\section{Introduction}

Most of the Earth's geological past is represented by the record of minute organic fossils. Precambrian sediments preserved a relative abundance of globally distributed marine and some hydrothermal and lacustrine aquatic microorganisms that are fundamental for understanding the early evolution of life and especially the origin and diversification of eukaryotes (Mendelson et al., 1992; Javaux et al., 2004; Grey, 2005; Knoll et al., 2006; Porter, 2006; Moczydłowska, 2008; Butterfield, 2009; Lamb et al., 2009; Moczydłowska et al., 2011; Strother et al., 2011). An initial step in tracing this process is the identification of phenotypic characters, metabolic processes, and modes of life in order to recognize phylogeny of the microfossils. The appearance of new morphotypes and innovative features in the context of the geological time may reveal major developments in the eukaryotic evolution. Traces of eukaryotes may extend as far back as at least $2 \mathrm{Ga}$ (Knoll et al., 2006; Hackett et al., 2007; Bhattacharya et al., 2009), or even earlier at $2.5 \mathrm{Ga}$ (Runnegar, 1994).

Our study of the c. $1.2 \mathrm{Ga}$ organic-walled microfossils Dictyosphaera and Shuiyousphaeridium from the Mesoproterozoic Ruyang Group of Shanxi Province in northern China, which are generally regarded as protists (Knoll et al., 2006), provides further evidence of their photosynthetic microalgal affinity. Gigantosphaeridium fibratum n.gen. et sp. is described and interpreted as belonging to the same group of microorganisms. New light microscope (LM) and scanning electron microscope (SEM) observations on Dictyosphaera and Shuiyousphaeridium have led to reinterpretation the organism's conspecificity and biological affinity, and to reconstruction of a potential reproductive life cycle. Activity of key eukaryotic organelles in these microorganisms is also inferred. Increased understanding of the phylogenetic relationships of the fossils studied, allows us to delimit the time of origin of the primary "green" group of photosynthesizing eukaryotes (Archaeoplastida) prior to $1.2 \mathrm{Ga}$.

Previous studies of the Mesoproterozoic biota established their relative diversity (Xing and Liu, 1973; Schopf, 1992; Yin, 1997; Xiao et al., 1997; Javaux et al., 2004; Huntley et al., 2006) and subsequently focused on their specific chemical properties (Kaufmann and Xiao, 2003; Marshal and Javaux, 2005; Meng et al., 2005; Javaux and Marshall, 2006). SEM and transmitted electron microscope (TEM) techniques (Javaux et al., 2004; Meng et al., 2005; Yin et al., 2005), in combination with ion and Raman spectroscopy analyses (Javaux and Marshall, 2006) illustrated the complexity of the vesicle wall and its biochemistry in Dictyosphaera and Shuiyousphaeridium. These are important features in distinguishing both a eukaryotic origin and 
their affinities. Several authors have interpreted these organisms as photosynthetic, unicellular plankton, at the base of green algae (Yin, 1997; Kaufmann and Xiao, 2003; Yin et al., 2005; Moczydłowska et al., 2011). We expand on this interpretation in the present paper through comparisons with extant eukaryotic and algal phenotypes.

Diversifications of green and red algal lineages, as well as heterotrophic protists occurred by a minimum age of $1.2 \mathrm{Ga}$, as indicated by the fossil record (Butterfield, 2000; 2004; Porter and Knoll, 2000; Porter, 2006). Single primary symbiosis and the origin of plastids that gave rise to Plantae (alternatively called Viridiplantae or Archaeplastida, Cavalier-Smith, 2003; Archibald and Keeling, 2002, 2004; Baldauf, 2008) are broadly estimated by molecular clocks to have evolved by $1.5 \mathrm{Ga}$ (Yoon et al., 2004; Hackett et al., 2007). The timing of this event in the paleontological record could be prior to $1.8 \mathrm{Ga}$, if the green algal affinity of leiosphaerid microfossils described by Lamb et al. (2009) is accepted (Moczydłowska et al., 2011). However, the "cryptic" intracellular evolution through which a cell acquired a characteristic eukaryotic architecture might have occurred before c. $2.1 \mathrm{Ga}$ (Runnegar, 1994).

The Mesoproterozoic Era (1.6-1.0 Ga) represents a crucial time for the rise of key innovations in cell complexity and genetic recombinations via endosymbiosis in single-celled organisms, as well as the origin of multicellularity. Often called the "boring billion" (Holland, 2006), this time interval may have been "dull" environmentally, but not cellularly. Brasier and Lindsay (1998) proposed a concept of eukaryotic evolution whereby a stable carbon cycle and low and stable nutrient levels allowed photosymbiotic relationships to stabilize over time, becoming an integral part of a eukaryotic cell. Furthermore, the increased morphological complexity of vesicle walls and filaments of organic fossils at this time (Butterfield, 2000; Javaux et al., 2004; herein) suggests intricate cellular machinery for cyst production and presence of the endomembrane system in addition to sexual reproduction.

Major acritarch characters, including those of the studied Ruyang biota, such as the lavish processes, complex cell wall and excystment structures, share morphological similarities and biochemistry with the cyst stage of extant chlorophytes, charophytes, and dinoflagellates (Lacalli, 1981; Blackburn and Tyler, 1981; Raven et al., 2005; Moczydłowska and Willman, 2009; Moczydłowska et al., 2011; Guiry and Guiry, 2013). As they represent elements of the reproductive cyst in modern taxa, sexual reproduction may also be assumed for the Mesoproterozoic fossils. Record of Ruyang fossils presented below suggests a sexual mode of life for the DictyosphaeraShuiyousphaeridium plexus. The two morphotypes indicate a bimodal life cycle and reproduction via the heteromorphic alternation of generations from a sexual (represented by a zygotic cyst-like Shuiyousphaeridium) to an asexual stage (the resting cyst-like Dictyosphaera). The main function of a reproductive cyst as a protective vesicle for daughter cells may explain the metabolically expensive, acetolysis-resistant, multi-layered cell walls that are present in Ruyang biota. Present-day analogues secrete composite membranes and other wall elements via the Golgi apparatus and endoplasmatic reticulum. Such organelles presumably arose early in eukaryogenesis (Stanier, 1970; Margulis, 1981; Dacks and Field, 2004;
Cavalier-Smith, 2006). The characteristic walls with reticulate sculpture and composite structure illustrated here suggest that key eukaryotic organelles were already present in the Mesoproterozoic.

\section{Geological setting}

Microfossils described here were extracted from the Mesoproterozoic sediments of the Ruyang Group exposed in the Shuiyou Section, Yongji district, Shanxi Province in northern China. The geologic succession has been thoroughly examined, and is well known both for its stromatolites and for the excellently preserved and readily extractable, diverse unicellular microfossils (Guan et al., 1988; Yin, 1997; Xiao et al., 1997; Kaufman and Xiao, 2003; Javaux et al., 2004; Yin et al., 2005; Meng et al., 2005; Yin and Yuan, 2007, Schiffbauer and Xiao, 2009). The Ruyang Group is un-metamorphosed and comprises a 380 $429 \mathrm{~m}$ thick succession of siliciclastic and carbonate rocks, which (in ascending stratigraphic order) is divided into the Baicaoping and Beidajian formations. The Ruyang Group unconformably overlies the Archaean crystalline basement with metamorphic age of c. $2350 \mathrm{Ma}$ (Xiao et al., 1997) and the volcanoclastics of the Paleoproterozoic Xionger Group, dated to c. $1760 \mathrm{Ma}$ (Zhao et al., 2002). The succession is overlain disconformably by several other Proterozoic formations and then by Neoproterozoic tillites and Cambrian strata (Guan et al., 1988; Yin, 1997; Yin et al., 2005). Within the overlying succession, the Cuizhuang Formation has been dated at $1125 \pm 3 \mathrm{Ma}$, providing a minimum constraint for the age of the Ruyang Group fossils (Liu et al., 1999).

The Baicaoping Formation consists of purple quartzose sandstones intercalated with organic-rich shales, succeeded by stromatolithic dolomites. The Beidajian Formation contains alternating quartzose sandstones, shales, and mudstones in a minor lower portion, and then dolomites with stromatolites and cherts (Guan et al., 1988; Yin, 1997).

Sandstone bedding surfaces in the Baicaoping Formation display ripple marks and desiccation cracks, indicating deltaic and near-shore marine depositional environments. The Beidajian Formation accumulated on a tidally influenced, shallow carbonate shelf with stromatolitic flats (Yin, 1997; Xiao et al., 1997; Yin et al., 2005). Fossiliferous beds are found in the upper grey and black shales of the Baicaoping Formation and the lower grey shales of the Beidajian Formation. Microfossils described here were extracted from a thin shale bed in the lower Beidajian Formation (see section by Yin, 1997).

The age of the Ruyang Group is estimated to be about 1100-1300 Ma based on K-Ar dating of glauconite from the neighboring Henan area (Guan et al., 1988; Yin, 1997; Yin and Yuan, 2007). Therefore the best estimate of the age of the microfossils is c. $1200 \mathrm{Ma}$ (Xiao et al., 1997; Yin et al., 2005). The chemostratigraphic profile of the group and $\delta^{13} \mathrm{C}$ data are compatible with global values for Mesoproterozoic carbonates (Xiao et al., 1997)

\section{Materials and methods}

Microfossils were extracted from four samples (beds Shanxi 9, $11,12,13)$ of dark, thin-bedded shales from a stratigraphic level 
$60 \mathrm{~m}$ above the base of the Beidajian Formation in the Shuiyou Section of Yin (1997). Preparation followed standard palynological method (Vidal, 1988). Two samples were re-processed as a double-check of the record (Shanxi 9, Shanxi 12). Rock fragments weighing c. $100 \mathrm{~g}$ were split into large chips and immersed into hydrofluoric acid $(40 \% \mathrm{HF})$ for several days. The resulting organic residue was separated into two batches, one of which was extracted after three and the other after six days, until the rock was completely dissolved. No difference in microfossil degradation was observed between the two batches. The residue was rinsed in water and decanted, then boiled in hydrochloric acid $(30 \% \mathrm{HCl})$ for $10 \mathrm{~min}$ to remove fluorides, then filtered through $18 \mu \mathrm{m}$ sieves. The residue was not oxidized. A Sartorius Teflon ${ }^{\circledR}$ membrane was used to filter the organic-rich residue. The residue was then rinsed in ethanol and acetone and centrifuged between rinsing for $3 \mathrm{~min}$ at $3000 \mathrm{rpm}$. Permanent strew mounts on microscope slides were produced using a synthetic resin EPO-TEK ${ }^{\circledR} 301$. Slides were cured at $50^{\circ} \mathrm{C}$ for $1 \mathrm{hr}$. Rigorous laboratory conditions and procedures prevented possible contamination.

Using high-concentration acids for extracting the microfossils revealed an important feature of their biochemical properties. Complex biopolymers composing the vesicle wall make it remarkably resistant to $\mathrm{HF}$ and $\mathrm{HCl}$ treatment, which dissolves nearly all of the enclosing minerals.

The microfossil collection and all illustrated specimens are stored in the collections of the Museum of Evolution at Uppsala University (under the prefix PMU). The position of the specimens in the microscopic slides is given using England Finder coordinates. The slides are orientated with their label to the left on the microscopic stage.

\section{Systematic paleontology}

Group Chloroplastida Adl et al., 2005

Phylum and class uncertain

Extinct Genera and Species

Genus Gigantosphaeridium new genus

Type species.-Gigantosphaeridium fibratum n. gen. et sp., from China, Shanxi Province, Shuiyou Section, upper Mesoproterozoic Erathem, c. 1.2 Ga.

Etymology.-From Latin gigantes, -um - giant, very large; sphaera - spheroidal in shape; referring to vesicle dimensions, which exceed the known size range of other unicellular microfossils in the Mesoproterozoic.

Diagnosis._As for the type species.

Remarks.-The new, monospecific genus Gigantosphaeridium has three distinct features: 1) a robust, opaque vesicle of large diameter with a psilate wall surface; 2) abundant and tightly arranged, solid, thin fibrilar processes; 3) a thin spheroidal membrane enveloping both the vesicle and processes. The vesicle diameter is wide-ranging, but there is a continuous array of vesicle sizes and no distinct size classes are recognized. The membrane is not always completely preserved and fibrilar processes are free exposed in some parts of vesicles with a disrupted membrane, indicating that the processes were not welded into the membrane, and also that they were composed of more resilient material than the outer envelope.

Dense distribution of processes distantly resembles the Ediacaran genus Appendisphaera. However Appendisphaera does not possess a membrane and its processes are hollow. Gigantosphaeridium has a smooth wall surface and it differs from Shuiyousphaeridium pilatum Li et al., 2012, which has a vesicle wall sculpture of a thin mesh diagnostic of the Dictyosphaera-Shuiyousphaeridium plexus. The diameters of the two species overlaps in size at their limits, but G. fibratum $\mathrm{n}$. gen. et sp. is considerably larger ( $\varnothing 150-595 \mu \mathrm{m})$ by comparison with $S$. pilatum $(\varnothing 50-190 \mu \mathrm{m})$.

\section{Gigantosphaeridium fibratum new species} Figure 1.1-1.5

Holotype.-Specimen PMU-S13-1-12-(Z/38/3); illustrated in Fig. 1.4.

Etymology.-The species name derives from Latin fibra, -ae fiber, filament; referring to the fibrilar or string-like shape of processes.

Material.-Nine well-preserved and adequately preserved specimens, sampled level M 9206 (by Yin, 1997), upper Mesoproterozoic Erathem.

Diagnosis.-Organic-walled, acid-resistant microfossil consisting of a very large vesicle, circular to oval in outline (originally spheroidal). The vesicle is robust and has a firm wall with a psilate surface and bears abundant, solid, homomorphic fibrilar processes, evenly and densely distributed over the entire vesicle surface. The vesicle, together with the processes, is enveloped by a thin, translucent membrane. Processes are predominantly simple, straight or slightly bent, and occasionally bifurcated terminally and connected to other processes. Process terminations may form small loops through connected tips. Process tips and loops support the surrounding membrane. Diameter is $150-595 \mu \mathrm{m}$ (holotype $595 \mu \mathrm{m}$ ); process length 7-27 $\mu \mathrm{m}$ (holotype $14 \mu \mathrm{m}$ ). $\mathrm{N}=8$.

Occurrence.-Mudstone of the upper Baicaoping Formation, Ruyang Group, Northern China, Shanxi Province, Shuiyou Section.

Remarks.-Considerable size variation among individuals (Fig. 1.) is indicative of growth phases. One specimen in the collection has much longer processes in a proportion to the vesicle diameter (Fig. 1.5) but the processes have identical morphology. They are free from the surrounding membrane. We include this specimen in the new species because only a single specimen with such distinct process morphology is available. It is possible that it represents a separate species if the lack of outer membrane is a consistent morphologic feature and not a result of the state of preservation. Specimens are generally well preserved and the vesicle wall is very firm and almost opaque, 


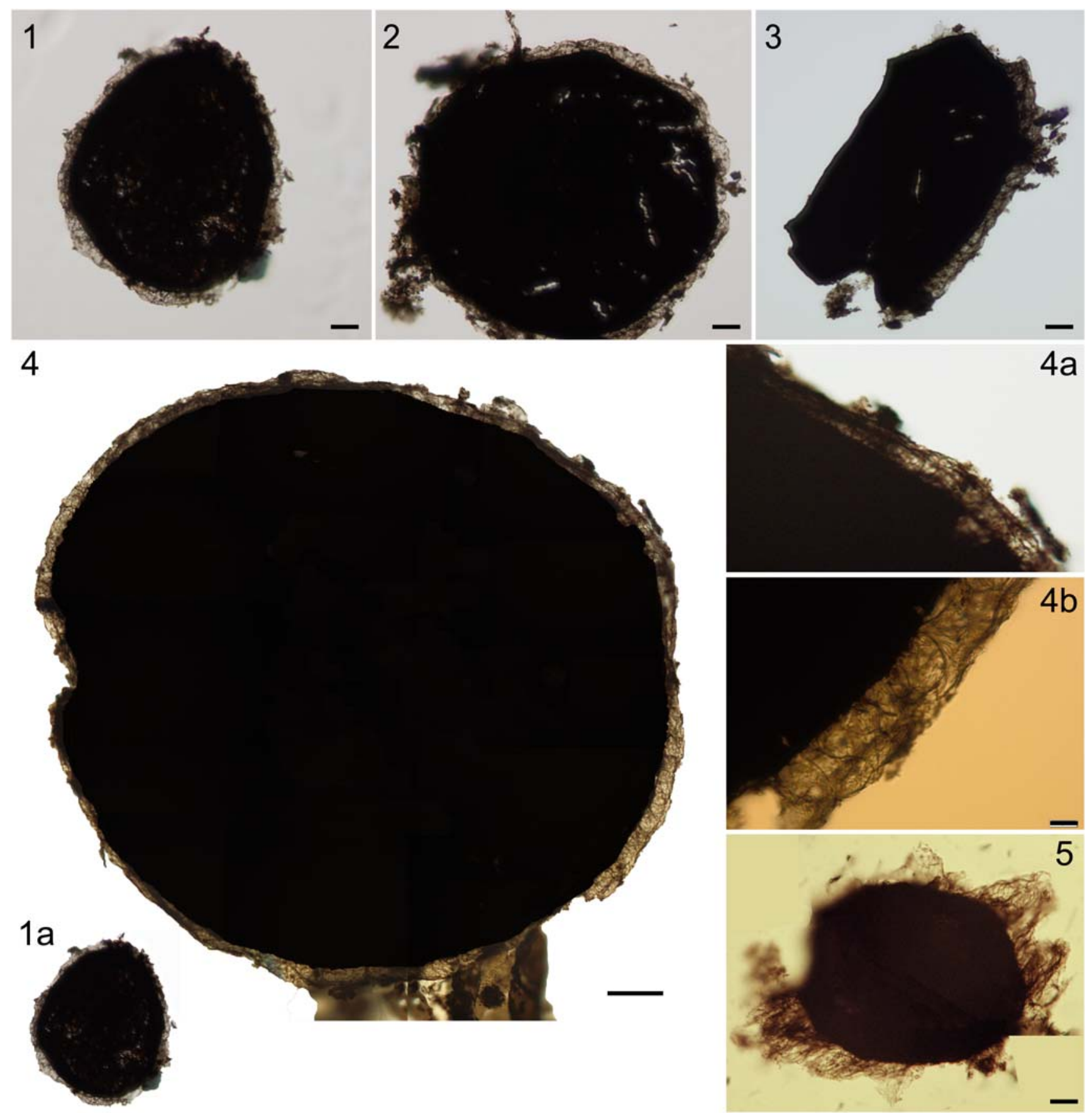

Figure 1. Morphology of organic-walled microfossils from the Mesoproterozoic Ruyang Group, Beidajian Formation, in Shanxi Province, northern China. 1-5, Light photomicrographs of Gigantosphaeridium fibratum gen. et sp. nov. (1, 1a) Specimen PMU-S13-1-11- (M40), shown at different scale. Image (1a) is under the same magnification as the holotype in (4), to demonstrate the wide size range of the new species. (2) PMU-S13-1-10- (P40/3). (3) PMU-S13-1-6(M46/3). (4) Holotype, composite digital image showing the large vesicle with fibrilar processes surrounded by translucent membrane. PMU-S13-1-12- (Z38/3). (4a, 4b) Magnified fragments of the vesicle in (4), showing upper right and lower right parts, respectively, at same magnification. (5) Specimen with much longer processes and tentatively assigned to the species, PMU-S13-3-20- (O49/2). All illustrated specimens are housed in the collections of the Museum of Evolution, Palaeontological Section, at Uppsala University, and are marked by prefix PMU-, followed by the Shanxi collection number S13-1-11, etc., and the England Finder coordinates (in brackets) in biological microscopic slides orientated to the right side by their labels. Scale bars equal $15 \mu \mathrm{m}$ for $\mathbf{1}$ and $\mathbf{5} ; 25 \mu \mathrm{m}$ for $\mathbf{2 - 3}$; $50 \mu \mathrm{m}$ for $\mathbf{4}$ and $\mathbf{1 a} ; 5 \mu \mathrm{m}$ for $\mathbf{4 a}-\mathbf{4 b}$.

varying in color between dark-brown and black $(\mathrm{TAI}=4$, value 2.5 on the Munsell pollen/spore colour standard). The color reflects the thermal alteration to certain extent but primarily results from the thickness of the cell wall and its robust structure. Some specimens display sharp fracture lines, which are taphonomically induced and confirm that the vesicle wall was rigid (Fig. 1.2 and 1.3). The degree of fracturing is generally lower than is observed in other Mesoproterozoic species, despite 
the large vesicle dimensions. In instances when the membrane is broken, individual processes are seen to rise independently from the vesicle surface, and these also show a resilient structure (Figs. 1.4a, 1.4b, 1.5).

\section{Genus Dictyosphaera Xing and Liu, 1973}

Type species.-Dictyosphaera macroreticulata Xing and Liu, 1973, from northern China, Yenliao region, Chih County of Hopei, Chuanlingkou Formation, lower Sinian system (Xing and Liu, 1973), now attributed to the upper Mesoproterozoic Erathem (Xiao et al., 1997).

1973 Dictyosphaera, Xing and Liu, p. 22, 58.

1982 Dictyosphaera; $\mathrm{Hu}$ and Fu, p. 108.

1988 Dictyosphaera; Du in Guan et al., p. 132.

1992 Dictyosphaera; Yan and Zhu, p. 274, 279.

2003 Dictyosphaera; Yin and Yuan, p. 40.

Remarks.-In the generic diagnosis (Xing and Liu, 1973, p. 22, 58 ), the vesicle diameter was given as " 10 micrometers" but it should be "10 to tens of micrometers", because they recognized species range consistently in diameter from 10-45 $\mu \mathrm{m}$. Both previously described species, D. macroreticulata and $D$. sinica, were described as having reticulate ornamentation on the vesicle surface and were distinguished by differences in the mesh diameter and the overall vesicle diameter. The given size differences are insignificant for identification and we consider the two morphotypes to be synonymous. D. macroreticulata is the senior synonym through priority in publishing. Several other subsequently described species of Dictyosphaera are treated as junior synonyms of $D$. macroreticulata in our taxonomic evaluation making the genus monospecific.

Similar patterns of surficial reticulation and overlap in vesicle size ranges of all previously described species of Dictyosphaera indicate that they are individual growth phases in ontogeny. We observe the same type of substantial size variability in Dictyosphaera (in the total record 10-274 $\mu \mathrm{m}$, and $28-240 \mu \mathrm{m}$, herein), in a comparable way as in the other genus, i.e. Shuiyousphaeridium, which is considered to be conspecific with Dictyosphaera (Xiao et al 1997; Kaufman and Xiao, 2003; Butterfield, 2005).

In our opinion, the genera Dictyosphaera and Shuiyousphaeridium represent various developmental stages (generations) in the life cycle of a single biological species. Either the two form-taxa can be maintained as morphotypes of distinct life stages within a Dictyosphaera-Shuiyousphaeridium plexus or they can be attributed to a single species in which Dictyosphaera macroreticulata Xing and Liu, 1973 would have taxonomic priority. Following the first option allows a better distinction of the morphology and clearer understanding of the various generations/life stages of extinct species. Such procedure is acceptable under the rules of I.C.B.N., giving form-taxa names for parts of fossil plants, such as spores, pollen, sporophytes and gametophytes.

Dictyosphaera macroreticulata Xing and Liu, 1973

Figure 2.1-2.9
Holotype.-Specimen inadequately illustrated for identification (Xing and Liu, 1973, pl. I:16) and not available for re-examination.

Lectotype.-The specimen originally assigned as the holotype of Dictyosphaera sinica Xing and Liu, 1973, and illustrated sufficiently well for identification by Xing and Liu (1973, pl. I:18) and which was derived from the same material as the holotype of $D$. macroreticulata, is here selected as the lectotype. The species $D$. sinica is considered here to be a junior synonym of D. macroreticulata Xing and Liu, 1973, and effectively, its holotype is chosen as the species lectotype because it has taxonomic priority.

1973 Dictyosphaera macroreticulata Sin et Liu, Xing and Liu, p. 22, 58, pl. I, 16-17.

1973 Dictyosphaera sinica Sin et Liu, Xing and Liu, p. 22, 58, pl. I, 18-19.

1982 Dictyosphaera delicata $\mathrm{Hu}$ et $\mathrm{Fu} \mathrm{Hu}$ and $\mathrm{Fu}$, p. 108, pl. II:3-6.

1982 Dictyosphaera gyrorugosa $\mathrm{Hu}$ et $\mathrm{Fu} ; \mathrm{Hu}$ and $\mathrm{Fu}$, p. 108, pl. III:1-3.

1982 Nucellosphaeridium areolosum $\mathrm{Fu}$ and $\mathrm{Hu}$ (sp. nov.) - $\mathrm{Hu}$ and $\mathrm{Fu}$, p. 109, pl. III:7-10.

1982 Incertae Sedis Type 3, Hu and $\mathrm{Fu}$, p. 110, pl. IV, fig. 14-15.

1982 Incertae Sedis Type 4, Hu and Fu, p. 110, pl. IV, fig. 16-17.

1982 Tasmanites tenellus, $\mathrm{Hu}$ and Fu, p. 113, pl. II:1.

1982 T. cf. volkovae, $\mathrm{Hu}$ and Fu, p. 113, pl. II:2.

1988 Dictyosphaera delicata; Du in Guan et al., p. 133, pl. 11: 4, 12.

1988 Dictyosphaera gurorugosa (sic!), Du in Guan et al., p. 133, pl. 11:5.

1988 Dictyosphaera dyrorugosa (sic!), Du in Guan et al., p. 200, pl. 11:5.

1988 Dictyosphaera macroreticulata; Du in Guan et al., p. 132-133, pl. 18:26.

1992 Dictyosphaera incrassata Yan, Yan and Zhu, p. 279, pl. II, figs. 1, 2.

1992 Dictyosphaera delicata, Yan and Zhu, p. 274 and 280, pl. II, figs. 3, 4.

1992 Dictyosphaera gyrorugosa, Yan and Zhu, p. 280, pl. II, fig. 5.

1992 Tasmanites? sp., Yan and Zhu, p. 280, pl. II, figs. 6, 7.

1992 Tasmanites aff. volkovae Kirjanov, Yan and Zhu, p. 280, pl. II, figs. 8-10.

1997 Dictyosphaera sp., Xiao et al., p. 205-206, figs. F, g.

2001 Dictyosphaera sp., Javaux et al., fig. 1e.

2005 Dictyosphaera delicata, Yin et al., p. 52, 53, fig. 2:1, 2, 5, 7, 9, 10.

2007 Dictyosphaera delicata, Yin and Yuan, fig. 1:1.

2012 Dictyosphaera delicata, Li et al., pl. I, figs. 3-15.

Material.-Around 100 specimens, including numerous entirely preserved specimens and, more commonly, fragmented specimens. 

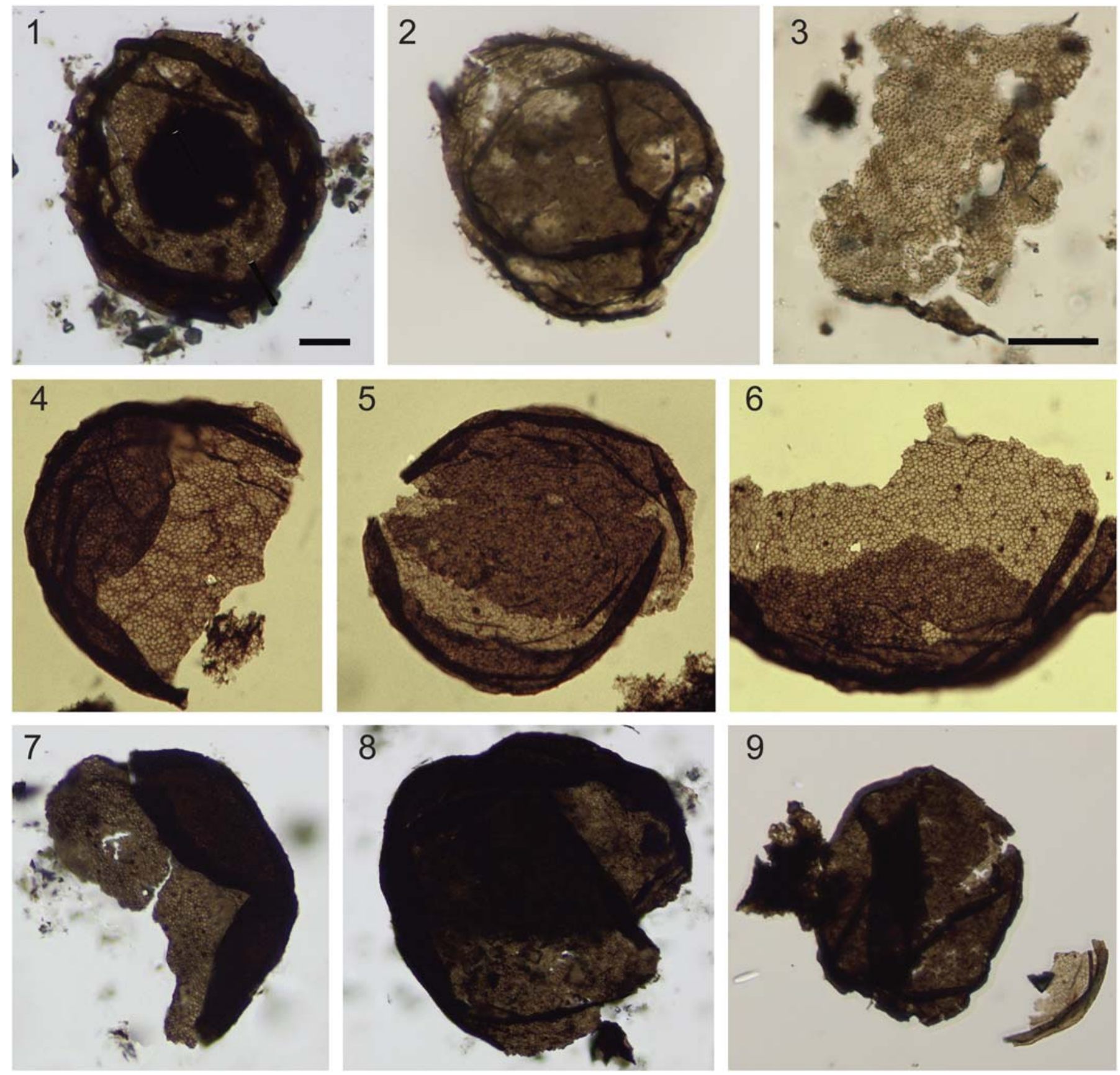

Figure 2. Light photomicrographs of Dictyosphaera macroreticulata in various states of preservation (1-9). (1) Specimen with internal body, PMU-S9-2-1(O44/3). (2) Vesicle empty inside, PMU-S9-2-12- (X40/1). (3) Fragment of the vesicle wall with polygonal meshwork, showing the highest resistance to degradation, PMU-S9-3-2- (C21). (4, 6) Pattern of penta- and hexagonal fields with different diameters on the single vesicle wall exposed in broken specimens, (4) PMU-S5-1-1- (K53/4), (6) PMU-S5-1-1- (W51/1-2). (5) Broken vesicle showing the disintegrating polygonal fields on the right side, PMU-S5-1-1- (M53/2), (7) PMU-S13-1-33- (B30/1). (8) PMU-S13-1-31- (Z32/2). (9) PMU-S11-1-1- (W49/4). Scale bar in 1 equals $20 \mu \mathrm{m}$ for 1, 2, 4-9 and scale bar in 3 equals 20 $\mu \mathrm{m}$.

Description.--Spheroidal vesicle having a reticulate surface sculpture formed by pentagonal and hexagonal low ridges with positive relief delimiting concave pits (mesh). The vesicle wall is two-layered. The external layer is reticulate with ridges protruding both externally on the surface and inwards into the vesicle cavity. The internal layer is composite and consists of interlocked, polygonal, organic platelets, which are embedded within the network of ridges of the external layer. Individual platelets are beveled along their sides and they interlock with each other with their shorter facets facing the cell cavity. On the internal vesicle-wall surface, the platelets also form a polygonal pattern but without relief. An excystment structure is present and consists of a partial rupture or simple median split, occasionally a circular opening (pylome) with a lid.

In our material, the vesicle diameter varies from $28-240 \mu \mathrm{m}$, and the average diameter of surface pits is $2 \mu \mathrm{m}(\mathrm{N}=83)$. The pits diameter is proportional to the diameter of the vesicle. Polygonal platelets from the internal layer range from 1-4 $\mu \mathrm{m}$ in width and 

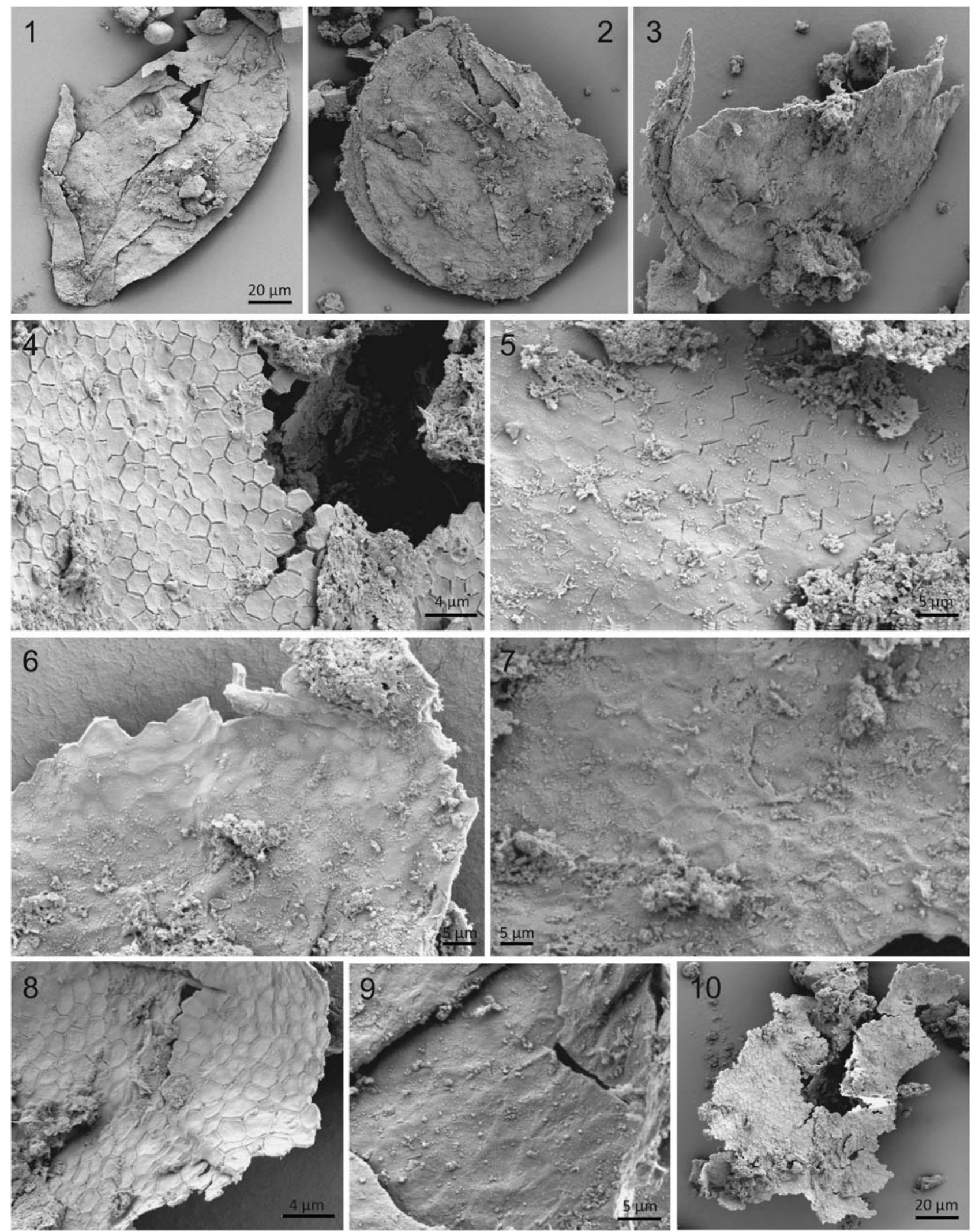

Figure 3. Scanning electron microscope (SEM) images of Dictyosphaera macroreticulata (1-10). (1, 2) Complete specimens, PMU-S12-1-18; PMU-S12-1-24 (3) Fragment of the vesicle showing the wall thickness, PMU-S13-1-1. (4-6, 8) Internal side of the vesicle wall with polygonal platelets, which are beginning to disintegrate $(\mathbf{4}, \mathbf{5})$ and their sides are seen at the lower central part of image in (4) and the lower right part of image in (8). Specimens PMU-S12-1-30b; PMU-S12-17b; PMU-S13-1-14a; MPU-S13-1-9a, respectively. (7, 9) Polygonal pattern with positive relief of ridges seen on the external side of the vesicle wall Specimens PMU-S13-1-6a; PMU-S13-1-11b, respectively. (10) Fragment of the wall with disintegrating polygonal platelets. Specimen PMU-S12-1-30a. Scale bar in $\mathbf{1}$ equals $20 \mu \mathrm{m}$ for $\mathbf{1 - 3}$, otherwise stated for each image. 

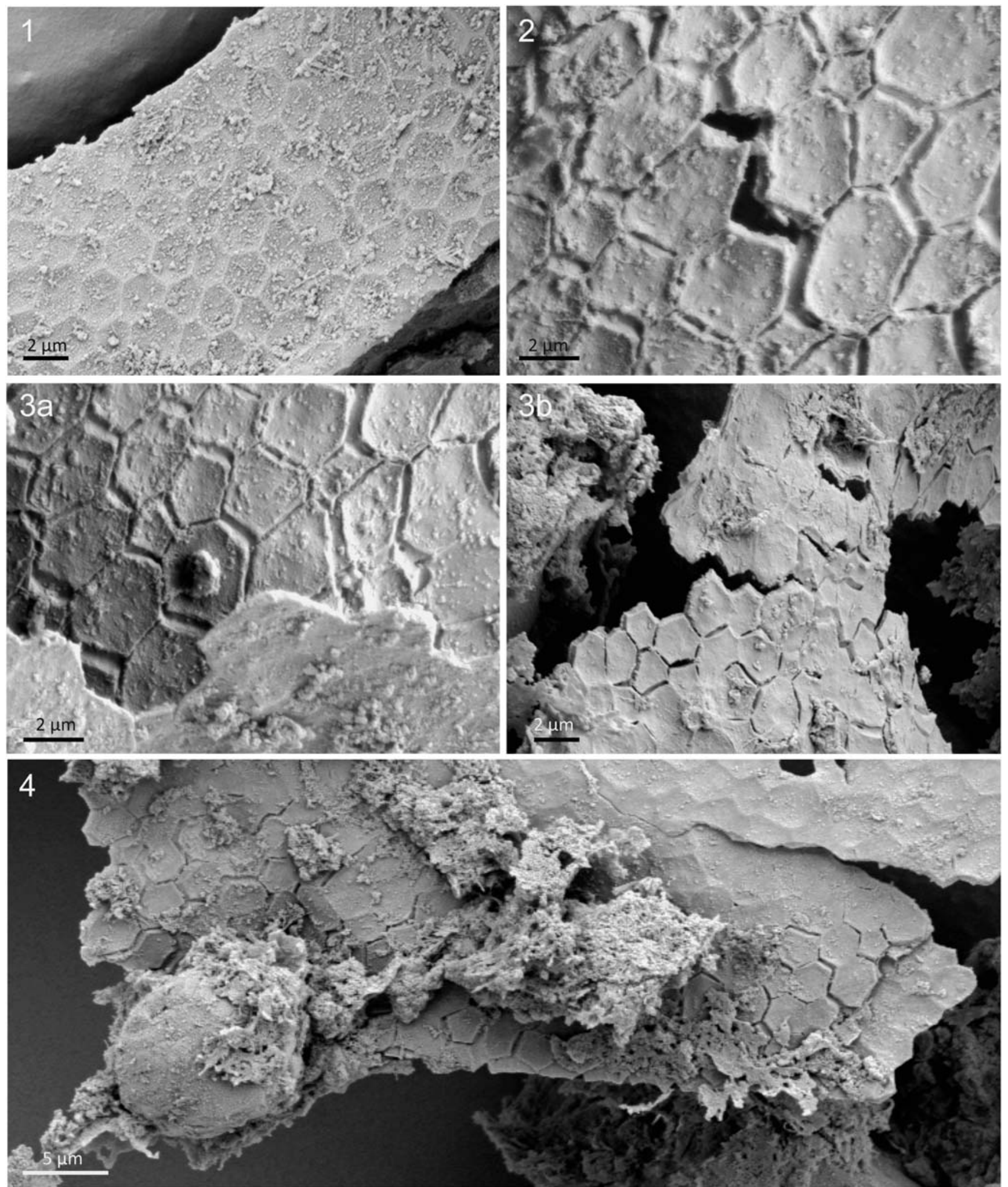

Figure 4. Cell wall structure of the Dictyosphaera macroreticulata in SEM images (1-4). (1) Internal wall surface with pattern of polygonal ridges without preservation of platelets. PMU-S12-1-18b. (2) Internal wall showing hexagonal and pentagonal platelets of various diameter beginning to disintegrate from their original tight alignment, thus showing their sides and thickness. PMU-S12-1-10d. (3a, 3b) Internal wall surface with details of platelets morphology in threedimensional appearance, seen underneath a broken vesicle wall (lower part of 3a). Possible bacterial growth on the platelet 3a. PMU-S12-1-10e. (4) Two-layered wall seen from the interior of the vesicle consists of the inner layer formed by interlocked platelets (secondary wall) and the outer layer with low polygonal ridges forming pits in which the platelets were located (primary wall). Both layers are exposed in the lower right corner of the image, where disintegrating platelets are detached from the pits but still lying on the outer layer. Gradual taphonomic alteration of the wall is seen in the upper right corner, where individual platelets are fading away and only polygonal ridges are still visible (scaffolding of the wall). Wall breakage develops along the angular edges of the polygonal platelets $\mathbf{2 , 3 b}, \mathbf{4}$. 

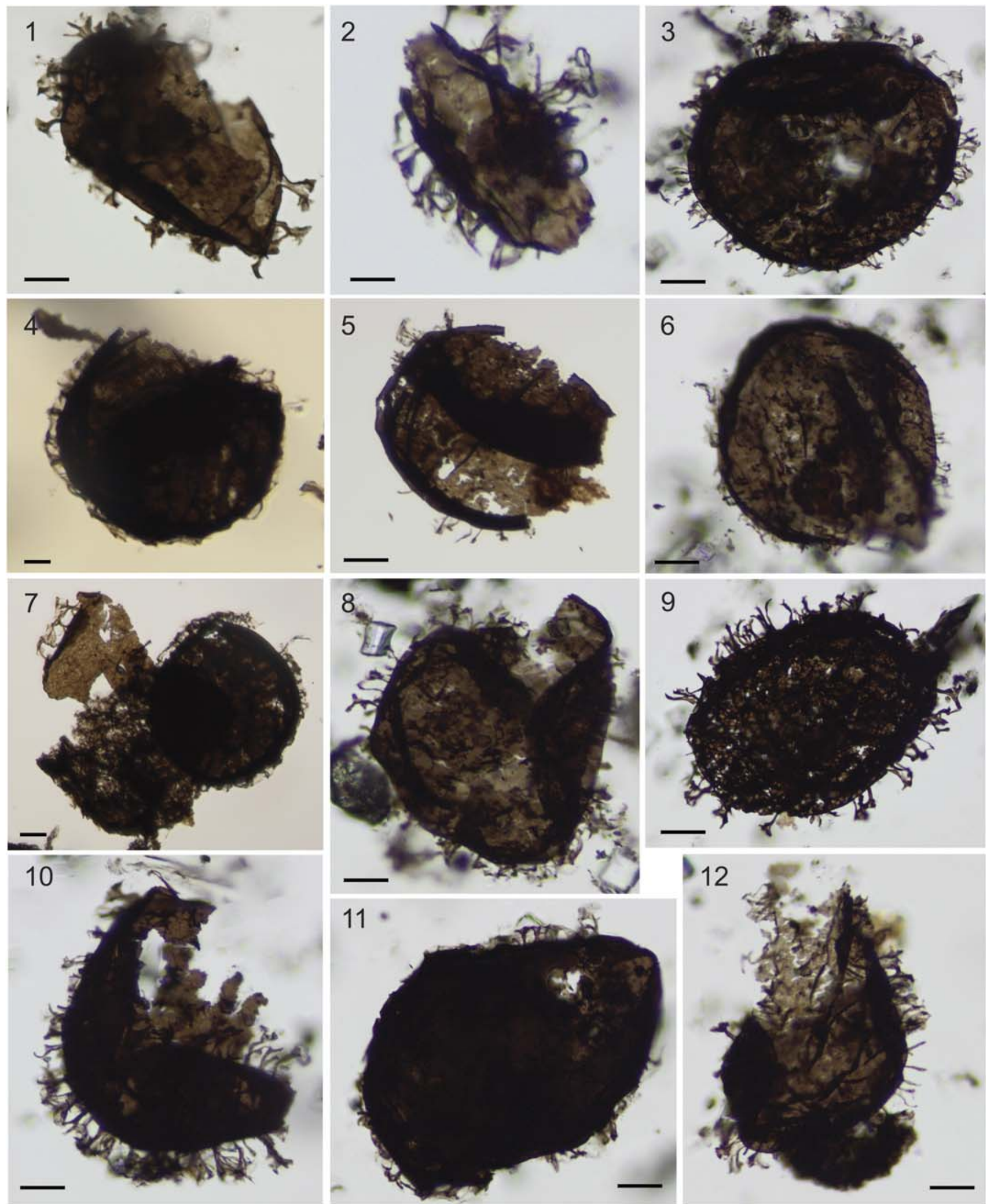

Figure 5. Light photomicrographs of Shuiyousphaeridium macroreticulatum in various states of preservation but with well-preserved processes (1-12). (1) Specimen showing thin solid processes with surrounding membrane forming distally flared portion (lower right side). PMU-S13-2-4- (D46/2). (2) PMUS12-1-14- (D47-1). (3) PMU-S12-2-6- (P48/3). (4, 7) Some processes are interconnected. PMU-S11-3-7- (N50/4); PMU-S13-1-15- (S21/1). (5) PMU-S113-22- (F37/3). (6) PMU-S12-2-7- (S50). (8) PMU-S12-1-34- (O30). (9) PMU-S12-2-8- (X48/3). (10) PMU-S12-2-9- (F40/1). (11) PMU-S12-2-1- (X34/3). (12) PMU-S12-2-3- (M33/1). Scale bars equal $25 \mu \mathrm{m}$ for all images. 

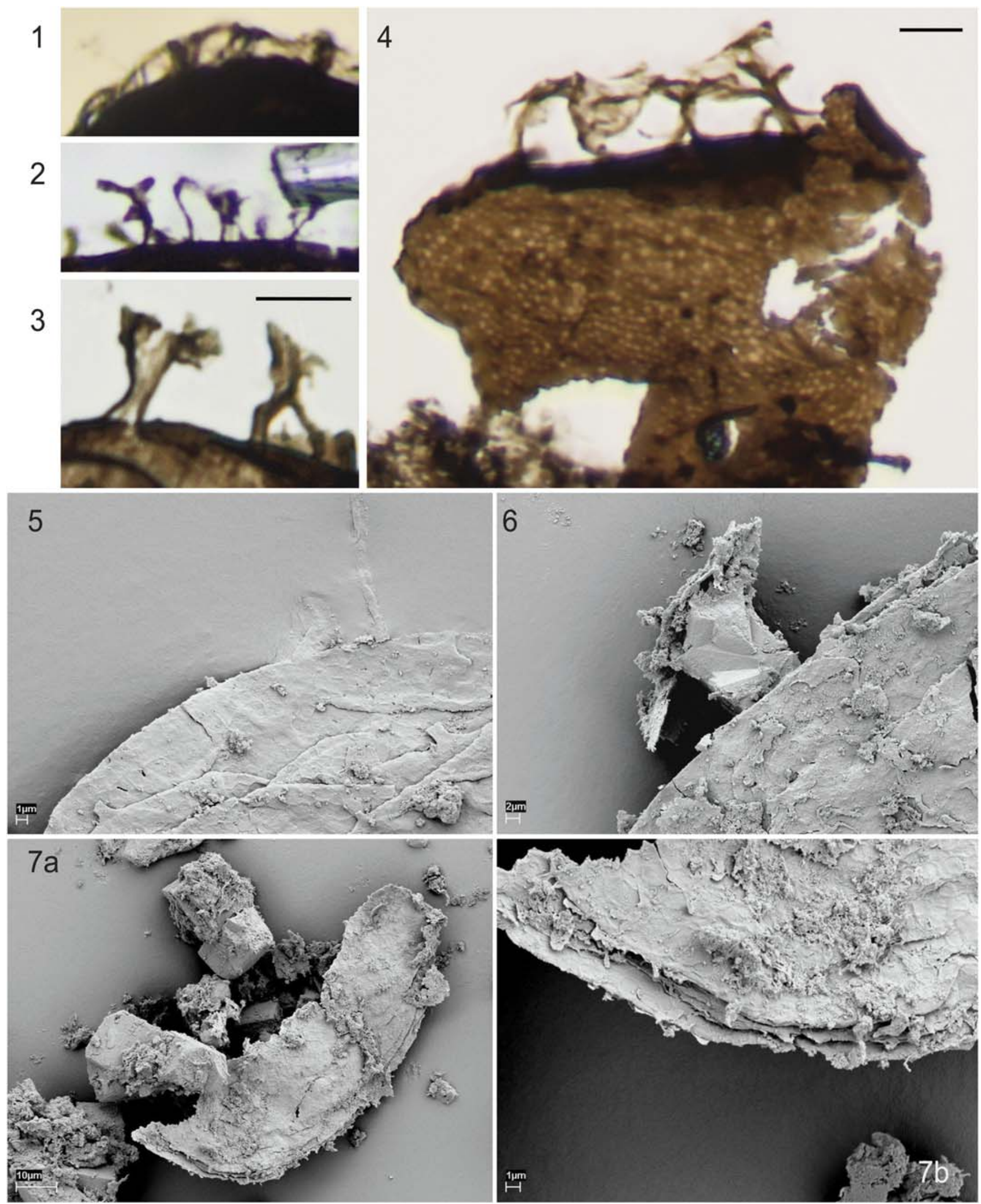

Figure 6. Process morphology in Shuiyousphaeridium macroreticulatum in light photomicrographs (1-4) and SEM images (5-7). (1) PMU-S11-3-7- (N50/4). (2) PMU-S12-1-34- (O30). (3) PMU-S12-2-4- (D46/2). (4) PMU-S13-1-15- (S21/1). (5) PMU-S12-1-19b. (6) PMU-S12-1-21a. (7a, 7b) PMU-S12-1-28. Enlarged fragment of the vesicle with processes (7b) from the lower part of specimen in (7a). Scale bar in (3) equals $10 \mu \mathrm{m}$ for photomicrographs in (1-3). Scale bar in (4) equals $15 \mu \mathrm{m}$. Otherwise stated in each SEM image. 
are 0.7-1.0 $\mu \mathrm{m}$ thick, and are also dependent on the overall size of the specimen. Records compiled from previous reports show that Dictyosphaera macroreticulata and its junior synonyms have a wide-ranging vesicle diameter, of between $10-274 \mu \mathrm{m}$, and the diameter of individual pits on the reticulate surface is $1-6 \mu \mathrm{m}$ (Xing and Liu, 1973; Hu and Fu, 1982; Yan and Zhu, 1992).

Occurrence.-Northern China, Hopei Province, Chuanlingkou Formation, Precambrian (Sinian System) (Xing and Liu, 1973); Shaanxi Province, Luonan County, Gaoshanhe Group, Mesoproterozoic (Hu and Fu, 1982; Xiao et al., 1997); Shanxi Province, Shuiyou Section in the Yongji district, the Ruyang Group, Mesoproterozoic, c. 1.2 Ga (Guan et al., 1988; Yan and Zhu, 1992; Xiao et al., 1997; Yin and Yuan, 2003; Yin et al., 2005; Yin and Yuan, 2007); Henan Province, Ruyang Group (Li et al., 2012). Northern Australia, the Roper Group, Mesoproterozoic, c. 1.5-1.4 Ga (Javaux et al., 2004).

Remarks.-We retain Dictyosphaera macroreticulata as the type species of the genus by selecting the lectotype from the same material as the holotype derived (I.C.B.N., Article 7.5). We consider four species previously assigned to the genus, i.e. $D$. sinica, $D$. delicata, $D$. gyrorugosa, and $D$. incrassata, to be junior synonyms of the type species. There is no objective feature that can be used to distinguish them, and they overlap both in morphology and in size classes. Of the other species, D. "polycerata" and D. "rugosa" (Chen, 1980; Lei, 1982) are nomen nuda (Fensome et al., 1990), and D. yunanensis Xing, 1982, described from early Cambrian strata (Xing, 1982), should be attributed to the genus Retisphaeridium Staplin et al., 1965.

Some specimens, which were attributed to Tasmanites, are synonymized herein with $D$. macroreticulata, because they show small holes within a vesicle wall that have been left by the decay of pits in the reticulate surface layer and the disintegration of platelets. These holes are a taphonomic feature and not morphologic punctuation of the vesicle wall, a feature that is diagnostic of Tasmanites.

Nucellosphaeridium areolosum is also similar to $D$. macroreticulata in morphology and dimensions, and which in addition possesses an internal body ( $\mathrm{Hu}$ and $\mathrm{Fu}, 1982)$, is here regarded as a synonymous taxon. The internal body could be shriveled cytoplasm, which coincidentally would appear as a lump of organic matter or an endocyst, if it is surrounded by its own wall. In the latter case, it would represent the reproductive stage of the same genus, i.e. Dictyosphaera (Fig. 2.1; see Life Cycle). Internal bodies preserved in D. delicata (Li et al., 2012, pl. I, figs. 3-12) are irregular lumps of organic matter, as are those in Shuiyousphaeridium pilatum (Li et al., 2012, pl. III, figs. 1, 2, 5, 7).

An internal body of very regular circular shape and delimited by a membrane, suggesting it is a true structural part of the vesicle, is preserved in one of the specimens previously reported (Yin et al., 2005, fig.2:5). We observe similar preservation in our material (Fig. 2.1). The internal body is indigenous to the vesicle because the vesicle is not broken and the body lies between the walls. We consider this structure as a putative endocyst developing inside a developmental stage of Dictyosphaera in which the meiotic division was occurring (Fig. 2.1; see Life Cycle). The endocyst is large in relation to the cell diameter, and this precludes interpreting it as a nucleus.

Opening of the vesicle by a rupture (Fig. 2.9) or median split (Fig. 2.5) is frequently observed. A large circular opening positioned in an apical part of the vesicle has also been recognized as an excystment structure in specimens attributed to Dictyosphaera sp. A (Yin et al., 2005, fig. 2: 3, 11, 12) and in D. delicata (ibidem, fig. 2:4). The presence of a small circular opening in a specimen of synonymous $D$. delicata by Yin et al. (2005, fig. 2:10) was suggested to be a pylome with a possible lid (Moczydłowska et al., 2011). The presence of a morphologically defined opening provides compelling evidence that the cell is a cyst. It has significant implications for the interpretation of life cycle of the Dictyosphaera-Shuiyousphaeridium plexus.

Genus Shuiyousphaeridium Yan in Yan and Zhu (1992), emend. Yin, 1997, emend.

Type species.-Shuiyousphaeridium macroreticulatum (Du in Guan et al., 1988) Yan 1992, emend. Yin, 1997, emended; northern China, Shanxi Province, Shuiyou section, Ruyang Group, Beidajian Formation, upper Mesoproterozoic Erathem (Du in Guan et al., 1988; Yan in Yan and Zhu, 1992; Yin, 1997).

Invalid genus 1988 Archaeohystrichosphaeridium Timofeev, 1956, Du in Guan et al., 1988, p. 144.

1992 Shuiyousphaeridium Yan, Yan in Yan and Zhu, 1992, p. 272, 278.

1997 Shuiyousphaeridium, Yin, p. 19.

2003 Shuiyousphaeridium, Yin and Yuan, p. 40.

2005 Shuiyousphaeridium, 1997 - Yin et al., p. 54.

2007 Shuiyousphaeridium, Yin and Yuan, p. 351.

Diagnosis.-As for the type species emended diagnosis.

Remarks.-The generic diagnosis was considerably emended by Yin (1997). We made minor modifications to include a multilayered wall and point out that the membrane may surround the entire vesicle, not just individual processes. TEM studies of the vesicle-wall ultrastructure showed that the wall is multilayered (Javaux et al., 2004; Yin et al., 2005). The wall may alternate between uni- or multi-layered, depending of the life stages (morphogenesis from vegetative to reproductive stage) in species with a complex life cycle and different ontogenetic developmental phases. Cell-wall ultrastructure may change as individuals grow and undergo metamorphosis between generations, especially where sexual reproduction and cyst formation is involved (Moczydłowska, 2010; Moczydłowska et al., 2011).

Shuiyousphaeridium macroreticulatum Yan, 1992, emend. Yin, 1997, emend.

Figures 5.1-5.12, 6.1-6.7

1982 Incertae Sedis Type 3 and $4, \mathrm{Hu}$ and $\mathrm{Fu}$, plate IV, figs. 14-17.

Invalid genus 1988 Archaeohystrichosphaeridium macroreticulatum Du, Du, 1988 in Guan et al., 1988, p. 144-145, pl. 11:13-14. 
Invalid genus 1988 Archaeohystrichosphaeridium cf. macroreticulatum $\mathrm{Du}, \mathrm{Du}, 1988$ in Guan et al., 1988, pl. 11:15-16.

1992 Shuiyousphaeridium macroreticulatum (Du) Yan gen. et comb. nov. - Yan in Yan and Zhu, 1992, p. 272, 279, pl. 1, figs. 1-6, 8 .

1992 Shuiyousphaeridium membraniferum Yan gen. et sp. nov. - Yan in Yan and Zhu, 1992, p. 273, 279, pl. 1, figs. 7, 9, 10 .

1997 Shuiyousphaeridium macroreticulatum (Du) Yan, emend. - Yin, p. 19-20, pl. I, 1-3, 5, 8; pl. II, 2, 5, 7, 8; fig. 3.

1997 Shuiyousphaeridium macroreticulatum (Du) Yan - Xiao et al., fig. 3 a, b.

2003 Shuiyousphaeridium macroreticulatum (Yan, 1992) emend. Yin, 1997 - Yin and Yuan, p. 43, pl. I, 4-7, 9.

2004 Shuiyousphaeridium macroreticulatum (Yan, 1992) Javaux et al., 2004, p. 127, fig. 5.

2005 Shuiyousphaeridium macroreticulatum (Yan and Zhou, 1982) (emend. Yin, 1997) - Yin et al., p. 54, fig 3:1, 2, 3, 6. (sic! Should be Yan and Zhu, 1992).

2007 Shuiyousphaeridium macroreticulatum (Du) Yan, emend. Yin, 1997 - Yin and Yuan, fig. 1:6.

2009 Shuiyousphaeridium macroreticulatum - Schiffbauer and Xiao, fig. 4A.

2011 Shuiyousphaeridium macroreticulatum - Schiffbauer and Xiao, fig. $13.6 \mathrm{c}$.

Material.-About fifty specimens, including numerous whole specimens as well as fragmented specimens.

Diagnosis.-Organic-walled microfossils consisting of a medium to large sized, circular to oval, sharply defined vesicle (originally spheroidal), possessing a surface sculpture of polygonal reticulation with a positive relief and bearing complex cylindrical processes. The vesicle wall is thick and multilayered in structure. Processes are numerous, may be relatively short to long, and are evenly or irregularly distributed over the entire vesicle. Processes are heteromorphic, cylindrical, flaring towards bifurcating, branching or funnel-shaped terminations, and either hollow and closed distally, or occasionally, simple and solid. Processes have conical bases or arise straight from the vesicle wall. Simple processes have truncate tips. Processes do not communicate with the vesicle cavity. A thin, psilate membrane may surround the whole vesicle or only certain processes or their branching terminations in a form of funnel or enclosing tube. The membrane closes the process but is concave towards the process basis, or it may stretch between neighboring processes. Process branches are often connected laterally. Excystment is either by a median split or a partial rupture.

Description.-Vesicle diameter $80-240 \mu \mathrm{m}$; process length 7-18 $\mu \mathrm{m}$; width of funnel-shaped process terminations $1-5 \mu \mathrm{m}$ $(\mathrm{N}=43)$. The vesicle diameter (compiled from previous studies) is $50-357 \mu \mathrm{m}$; process length $2-45 \mu \mathrm{m}$; process branches $1-25 \mu \mathrm{m}$ long; width of funnel-shaped process terminations 1-5 $\mu \mathrm{m}$; and the width of process bases 0.5-3.0 $\mu \mathrm{m}$. The vesicle wall is $0.5 \mu \mathrm{m}$ thick (Yin, 1997; Xiao et al., 1997; Javaux et al., 2004; Yin et al., 2005; Yin and Yuan, 2007).

Occurrence.-Northern China, Shaanxi Province, Luonan County, Gaoshanhe Group (Hu and Fu, 1982); Shanxi Province, Shuiyou Section in the Yongji district, the Ruyang Group, Mesoproterozoic, c. 1.2 Ga (Guan et al., 1988; Yan and Zhu, 1992; Yin, 1997; Xiao et al., 1997; Yin and Yuan, 2003; Yin et al., 2005; Yin and Yuan, 2007). Northern Australia, the Roper Group, Mesoproterozoic, c. 1.5-1.4 Ga (Javaux et al., 2004).

Remarks.-The type species of two genera, Dictyosphaera and Shuiyousphaeridium, were named "macroreticulata" and "macroreticulatum", respectively, indicating that the same morphologic feature, a reticulate vesicle surface, is present in both. Xiao et al., (1997) suggested that the taxa are conspecific and that taphonomic loss accounted for the lack of processes in Dictyosphaera macroreticulata. If the taxa are conspecific, Dictyosphaera macroreticulata is the senior synonym and has priority. Taphonomic loss of processes is likely to be only partial, so would be insufficient to produce a process-less morphotype. We therefore suggest that Dictyosphaera and Shuiyousphaeridium are morphologically distinct cysts and consequently prefer to retain both form-genera, but recognize them as developmental stages in a life cycle of a single biological species (see Life Cycle).

\section{The cell-wall structure}

New LM and SEM observations on the cell-wall structure of the Dictyosphaera-Shuiyousphaeridium microfossil plexus extend previous studies based on various microscopic techniques (Kaufman and Xiao, 2003; Javaux et al., 2004; Yin et al., 2005; Schiffbauer and Xiao, 2009, 2011), and corroborate certain features of the wall layering and its construction. Some features are reinterpreted, and morphological and structural differences between the two taxa infer a sequence of developmental changes in the life cycle of a single biological species. Overall morphology and the reticulate cell-wall sculpture suggest that the genera are conspecific. The lack of processes in Dictyosphaera was assumed to be due to diagenetic or sample processing loss, whereas their presence in Shuiyousphaeridium was viewed as a probable developmental feature (Xiao et al., 1997; Kaufman and Xiao, 2003; Butterfield, 2005). However, taphonomic processes or destructive laboratory procedures would not normally result in a total removal of processes in certain specimens (producing Dictyosphaera) or their complete preservation in others (Shuiyousphaeridium). Moreover, both morphotypes are present in the same samples and macerates. Loss of processes normally leaves attachment-point scars on the vesicle surface (Moczydłowska and Nagovitsin, 2012).

Xiao et al. (1997) assumed that processes were a developmental feature found only in larger individuals, as represented by Shuiyousphaeridium, after reporting that Dictyosphaera vesicles are smaller than those of Shuiyousphaeridium, thus implying that processes grew outwards from the cell surface in 

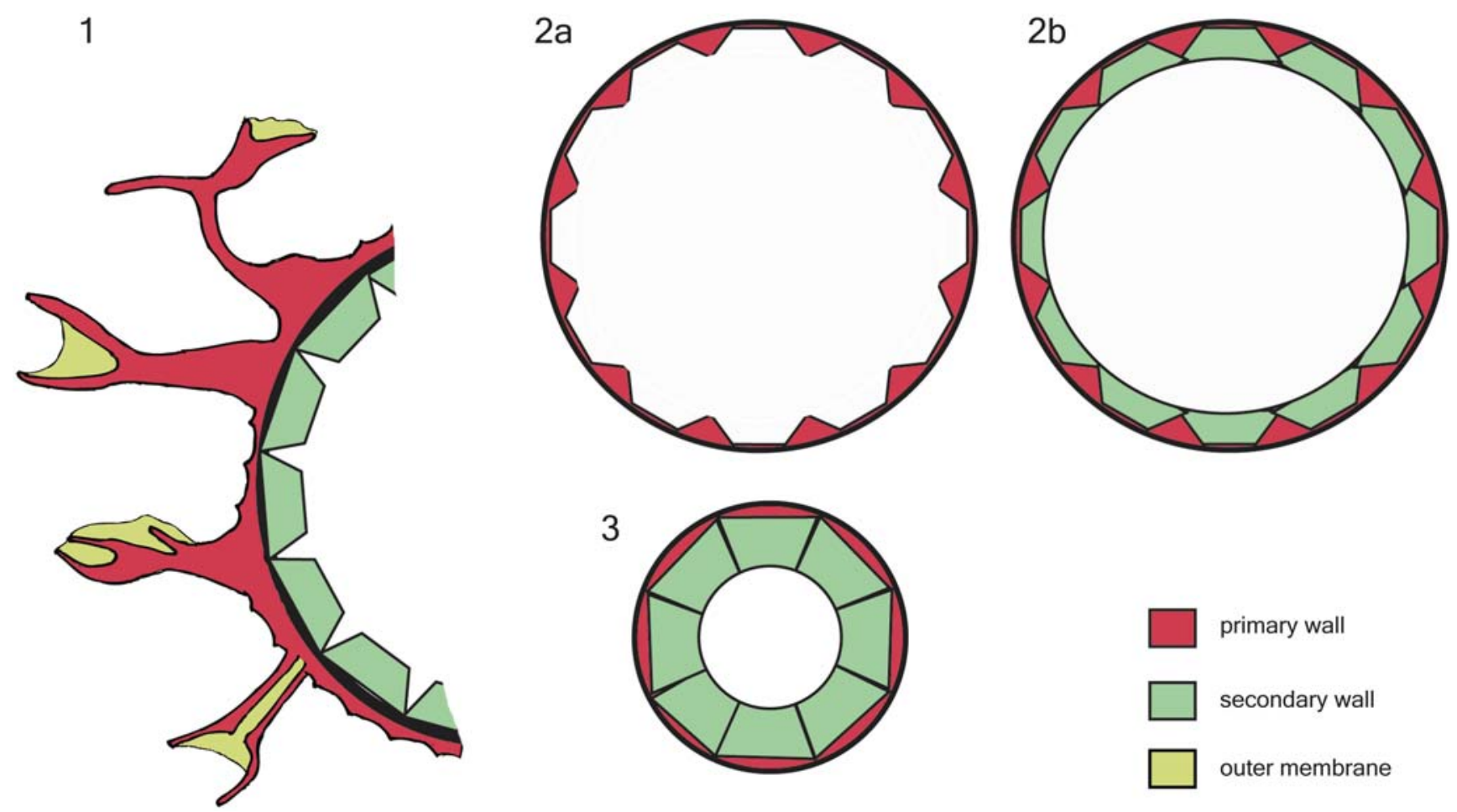

primary wall

secondary wall

outer membrane

Figure 7. Wall structure of microfossils in the Dictyosphaera-Shuiyousphaeridium plexus, Fossil morphotypes differ by the absence/presence of processes respectively, but have identical wall structure $(\mathbf{1}, \mathbf{3})$. Two layers in the microfossils' wall are inferred to constitute the primary wall (PW) and the secondary wall (SW) of the cyst stage, by comparison to wall structure in extant microalgae. Taphonomic changes, notably the compression of spheroidal cells, deformation of the walls and disintegration of platelets causing their separation, are herein distinguished from true morphologic and structural features. Length and thickness of processes, vesicle dimension and the wall structure elements and thickness are not to scale.

ontogenetically older individuals. This explanation cannot be sustained because both taxa largely overlap in their size ranges. Additionally, both morphotypes share a cyst-like morphology and wall sculpture. During morphogenesis from vegetative or zygotic cell into cyst, cytoplasm contracts from the cell wall, leaving strands that develop into processes, as observed in most extant algal microorganisms with known life cycle (Dale, 1983, 2001; van den Hoek et al., 1995; Belmonte et al., 1997; Raven et al., 2005). Multiple developmental mechanisms do involve processes growing outwards from the cytoplasm surface in a few dinoflagellate species (Kokinos and Anderson, 1995), but this reflects their highly derived phylogenetic position (Delwiche, 2007).

The wall structure of Dictyosphaera was previously examined in $D$. delicata by LM, TEM, a field-emission scanning microscope (FE-SEM), and a focused ion beam electron microscope (FIB-EM) by Yin (1997), Xiao et al. (1997), Kaufman and Xiao (2003), Yin et al. (2005), and Schiffbauer and Xiao (2009). Synonymous Dictyosphaera macroreticulata was herein recognized as multilayered, having a reticulate surface and consisting of interlocking polygonal plates (platelets herein) on the inner side of the wall (LM, TEM; Yin et al., 2005). In FIB-EM nanotomography, the wall was observed to be multilamellar and 200-500 thick (Schiffbauer and Xiao, 2009). The wall showed inner incisions corresponding to the boundaries between the polygonal plates, although the ridges on the wall surface were not depicted in cross-sections. From our material, it seems that the incisions are taphonomic rather than morphological and result from the plates breaking apart in a flattened specimen. The outer edge of the vesicle wall in the FIB-EM section shows very regular chambers of unknown origin (Schiffbauer and Xiao, 2009, fig. 3K). Similar structures observed in Shuiyousphaeridium macroreticulatum were interpreted as sections of the bulbous tips of processes beneath a membrane shrouding them. It seems more likely that these structures in both taxa are artifacts introduced during diagenesis, or while preparing and coating the specimens. The "bulbous structures" are similar to artifacts of burial diagenetic processes affecting carbonaceous walls of other microfossils and producing apparent structures resembling "rounded chambers" or process-like "saw-tooth patterns" of carbonaceous material. Such structures were analyzed by FIB-SEM and FIB-TEM in cell walls of the spheroidal microfossil Huroniospora well preserved by permineralization from c. $1.9 \mathrm{Ga}$ Gunflint chert (Wacey et al., 2012). The structures were recognized as the effects of taphonomy, inducing an artificial wall texture (Wacey et al., 2012), although it was originally identified as a species-diagnostic morphology (Barghoorn and Tyler, 1965; Hofmann, 1971; Schopf, 1992).

Our new reconstruction of cell-wall structure and of a life cycle for the Dictyosphaera-Shuiyousphaeridium plexus discriminates between taphonomic states and ontogenetic stages.

Taphonomic processes are not always destructive and may enhance the visibility of certain features, such as the habit of individual platelets and their embedment in the cell-wall layer, a feature observed only in broken specimens. Alteration in progressively disintegrating specimens can be very informative about the robustness of discrete wall elements, and perhaps reflects the diverse chemistry present at different layers in organic wall. 
The cell wall in Dictyosphaera macroreticulata is twolayered and consists of an outer layer with low polygonal ridges on both sides, and an inner layer formed by polygonal interlocked platelets (Figs. 3.7, 3.9, 4.1, 4.2). The outer layer has more prominent ridges on the wall surface (seen as reticulation with a positive relief) than those protruding inwards to form the pits, which embedded platelets in the inner layer (Fig. 4.4).

The ridges are hexa- and pentagonal in planar view but in a three-dimensional (3D) reconstruction have a honeycomb structure. The inner layer is comprised of laterally interlocking platelets that are tightly aligned in a polygonal pattern lacking relief. It is only when platelets begin to disintegrate that low ridges directed towards the cell cavity become visible, revealing that the platelet bases are embedded in pits formed by these ridges (Fig. 7). Platelet facets are hexagonal to occasionally pentagonal conforming to the polygonal ridges (Fig. 4.2). Platelets are trapezoidal in lateral cross-section.

The outer reticulate layer is composed of resistant organic matter so its ridges survive prograding taphonomic alteration longer (Figs. 2.4-2.7). The ridge-delineated pit bottoms decompose more readily, turning into holes (Fig. 2.6). The reticulate outer layer acts as scaffolding for the cyst wall, and is the primary wall (PW), (Fig. 7). The inner composite layer is the secondary wall (SW). This is the first record of a composite organic secondary wall composed of individual platelets in microfossils. A secondary wall was previously recognized in Cryogenian Leiosphaeridia-like microfossils as a continuous and homogeneous sub-layer underlying the trilaminar sheath structure (TLS) in a multilayered cell wall (Moczydłowska et al., 2010). Similarly, a secondary wall lies beneath the TLS in the early Cambrian leiosphaerids with inferred chlorophycean affinities (Talyzina and Moczydłowska, 2000; Moczydłowska and Willman, 2009), and in Mesoproterozoic leiosphaerids interpreted as eukaryotic protists (Javaux et al., 2004), or as chlorophycean microalgae (Moczydłowska, 2010; Moczydłowska et al., 2011), although we believe the secondary wall was not identified as such until now.

In Shuiyousphaeridium macroreticulatum, the multilayered cell wall was observed in SEM and TEM studies (Javaux et al., 2004; Yin et al., 2005). In SEM images, reticulation on the cell-wall surface is mirrored on the inner surface and the ridges correspond in shape and size to hexagonal and pentagonal plates (herein platelets), which were thought to be defined by incisions seen in TEM images on the inner wall surface (Javaux et al. (2004).

Furthermore, Javaux et al. (2004) recognized a threelayered cell-wall structure in a TEM thin section of Shuiyousphaeridium macroreticulatum, by a means of differing electron density of its organic matter and the topologic extension of the layers. They interpreted the outermost layer as consisting of debris and sectioned processes, a second, reticulate layer as a homogeneous, electron-dense layer of ridges on the outer surface and incisions on the inner surface with organic plates located between the incisions, and a third, innermost layer as a thin electron-tenuous layer that lines the inner sides of the plates.

In the interpretation of the Shuiyousphaeridium cell-wall by Javaux et al. (2004), it is not clear whether the first layer and the debris are remains of disintegrated surface layer that formed the processes, or the membrane that is seen in LM images and preserved in fragments on the cell-wall and surrounding the processes (Yin, 1997; Xiao et al., 1997; Yin et al., 2005; Schiffbauer and Xiao, 2009; Fig. 6.1, 6.3, 6.4). However, neither the process sections nor the surface reticulation relief are seen in TEM images. We consider the incisions in the second layer to be a taphonomic feature due to disintegration and separation of the interlocked platelets from their original spherical alignment. Seen in the TEM thin section of compressed wall of a once spheroidal cell, the platelets on the wall's internal surface appear widely separated by incisions as a result of cell deformation and wall breakage. In the SEM images (Javaux et al., 2004), the platelets are tightly arranged, and this is also demonstrated in our material. Our interpretation is that the platelets belong to a composite (although separate) layer in the wall, i.e., the secondary wall, whereas the homogeneous layer forming the superficial and interior-facing ridges is the primary wall (Fig. 7). The third layer forming an inner lining of the cell wall (Javaux et al., 2004, fig. 5h) is difficult to see in the TEM section.

We consider the cell-wall structures of Dictyosphaera and Shuiyousphaeridium to be homologous because of the shared features. There are two layers: the outer reticulate layer as the primary wall, and the inner composite layer of platelets formed as the secondary wall for the additional strength and protection of the cyst (Fig. 7). The difference between the two taxa is the absence or presence of processes, respectively. We regard this difference as indication of distinct cyst stages (asexual and zygotic, respectively) in the life cycle of a single species (Fig.8).

If correct, this is the earliest example of sexual heteromorphism in photosynthetic protists, although this represents generational variation (asexual vs. sexual) rather than sex (female versus male morphs) differences.

\section{Life cycle}

The common morphological characteristics and biochemical properties (i.e., resistant organic vesicle, ornamentation and diverse processes, and excystment structures) in ancient organic-walled microfossils (acritarchs) have long been considered as features of a reproductive cyst stage of phytoplanktonic protists (Tappan, 1980; Moczydłowska, 1991, 2010; Grey, 2005; Wicander, 2007). Ultrastructural studies on organic walls in Proterozoic and Cambrian microfossils (Arouri et al., 1999, 2000; Talyzina and Moczydłowska, 2000; Kempe et al., 2002, 2005; Javaux et al., 2004; Willman and Moczydłowska, 2007; Moczydłowska and Willman, 2009; Schiffbauer and Xiao, 2009; Willman, 2009; Moczydłowska et al., 2010) reinforced this interpretation by identifying significant complexity and multilayering comparable to that in modern photosynthesizing protists and certain microalgal species. Phylogenetically diverse protistan clades are known to produce preservable cysts as a part of their life and reproduction cycle, regardless of whether they are asexual (i.e., prasinophyte resting cysts) or sexual (zygotic cysts in chlorophytes, charophytes, and dinoflagellates) (Evitt, 1985; Margulis et al., 1989; Dale, 2001; Hagen et al., 2002; Raven et al., 2005; Damiani et al., 2006; Head et al., 2006). Cyst wall resistance (preservability without permineralization) demonstrates specific requirements for successful reproduction: the protection of the maturing zygote (Graham and Wilcox, 2000; 


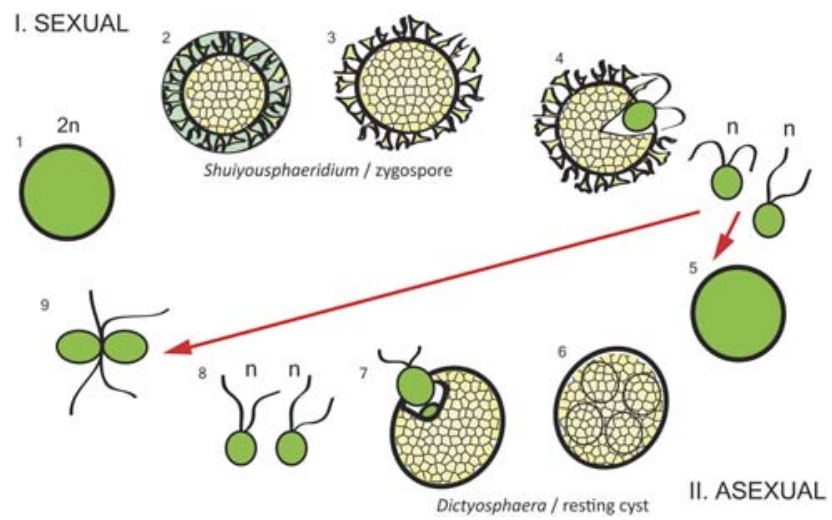

Figure 8. Reproductive life cycle model reconstruction for DictyosphaeraShuiyousphaeridium, based on reproductive cycles of modern chlorophytes. (1) Zygote, start of the sexual reproduction. (2) Shuiyousphaeridium morphotype, cyst shrinkage produces processes. (3) Outer membrane is discarded, meiosis occurs. (4) Haploid offspring is released through the excystment structure. It may fuse into another zygote (9) or form a resting cyst (5). (6) Start of asexual reproduction and resting cyst formation, mitosis occurs in Dictyosphaera morphotype. (7) Offspring is released through the excystment opening. (8) Flagellated haploid offspring. (9) Fusion into a zygote.

Moczydłowska et al., 2011). The synthesis of sturdy walls in reproductive stages involves the secretion of additional layers to those present in vegetative cell walls. This requires a significant metabolic investment, but yields a more successful reproduction. Additionally, sturdy walls provide an ecological advantage for coping with high deep-water pressure in cysts that rest periodically on bottom sediment (Mendelson, 1993; Reynolds, 2006).

The diverse processes in microfossils, including those in Dictyosphaera-Shuiyousphaeridium, show the same complexity and morphologic patterns as in extant phytoplanktic cysts, where their function is to maintain buoyancy and sensory activity. Ornamented-cyst processes act as floatation devices enabling passive migration or suspension in the water column (e.g. within the photic and oxygenated surface zone). Eventually they aid descent to the substrate, where cysts remain for releasing offspring or dormant under adverse environmental conditions (e.g., low nutrients supply, temperature change, acidity or anoxia) (Blackburn and Tyler, 1981; van den Hoek et al., 1995; Belmonte et al., 1997; Dale, 2001; Reynolds, 2006; Lee, 2008). Excystment structures (reproductive openings) develop once a cyst has matured to release offspring (Tappan, 1980; Bold and Wynne, 1985; Wicander, 2007; Moczydłowska, 2010). The structure can be a simple split or physiologically controlled, rounded opening. Both excystment structures are present in Dictyosphaera and Shuiyousphaeridium. However, only low numbers of cysts are likely to be preserved after excysting because open cysts are more prone to biodegradation. Consequently, fossil excystment structures are seldom observed (Moczydłowska and Willman, 2009).

Examination of key morphological and structural features and their function in the Dictyosphaera and Shuiyousphaeridium microfossils allows reconstruction of a life cycle as exemplified in the Cambrian organic-walled microorganism Skiagia (Moczydłowska, 2010).

The structural evidence presented here supports the previous suggestion of Xiao et al. (1997) that the two morphotypes are conspecific and represent different life stages of a single biological species of eukaryotic affinity.
The cyst-like morphologies in Dictyosphaera and Shuiyousphaeridium, suggest bimodal reproduction, by alternation of generations (Fig. 8). The life cycle model is inferred by comparison with extant green microalgae (chlorophytes, charophytes, and dinoflagellates), (Margulis et al., 1989; Melkonian, 1989; van den Hoek et al., 1995). Alternation of sexual and asexual reproduction in individual species is genetically driven as part of a regular life cycle or induced ecologically as a means of overcoming adverse conditions (Lewontin, 1958; Pfiester and Anderson, 1987; Bateman and DiMichele, 1994; 1994; Sarjeant and Taylor, 1999; Kaltz and Bell, 2002; Reynolds, 2006; Graham et al., 2008; Lee, 2008). Both generations usually differ in the morphologic appearance of their cysts, and are distinct from flagellate vegetative cells. This may be observed in a number of modern taxa, such as the chlorophyte Chlamydomonas (van den Hoek et al., 1995).

The reconstructed life cycle of the Dictyosphaera and Shuiyousphaeridium plexus is as follows. Sexual reproduction begins when the haploid, vegetative cells pair and fuse into a zygote, which loses its flagella and subsequently produces a diploid cyst with an ornamented wall (Fig. 8.2). The Shuiyousphaeridium macroreticulatum morphotype represents this stage and its morphology resembles cysts seen in several extant species. A common pattern of acanthomorphic zygotic cysts is known in microalgae, such as the chlorophycean Golenkinia radiata (Chodat, 1894; Guiry and Guiry, 2013), the charophyte desmidiaceans Micrasterias papillifera (Kies, 1970) and Micrasterias thomasiana (Blackburn and Tyler, 1981), and the zygnemophycean Staurastrum fungicerum (Lacalli, 1981). During zygotic cyst formation in Micrasterias thomasiana (Blackburn and Tyler, 1981), the cytoplasm begins to shrink inwards and spiny processes are formed by contraction from the outer membrane enclosing the zygote (Belmonte et al. 1997; Lee, 2008). This ornamented cyst harbors the zygote and the ensuing meiotic subdivision, while the outer membrane is discarded. In Shuiyousphaeridium, remnants of the thin outer membrane, which may be analogous to the zygotic membrane, are observed as fragments surrounding the processes (Fig. 6.3 and 6.4), either engulfing several processes (Fig. 5.4 and 6.1), or as conjoined, uneven, membranous flaps (e.g., in the synonymous $S$. membraniferum).

The thin outer membrane is discarded after the sturdy cyst represented by Shuiyousphaeridium has been formed (Fig. 8.3.). This cyst is characterized by distinctive processes and the wall is reinforced by resistant-biopolymer(s) in the primary and secondary walls. It compares to the modern genus Micrasterias whose walls are reinforced by fusion of the Golgi septum vesicles with the plasma membrane (Lütz-Meindl and BrochSalomon, 2000). Alternatively, the cyst may settle to the bottom as benthic plankton, a periodic mode of life common in extant microalgae (Dale, 1983). Meiosis presumably occurs within the zygocyst, either floating or resting in the sediment. Haploid offspring is released through the excystment structure. Matured haploid vegetative cells may yield another zygotic cycle or may reproduce asexually.

During asexual reproduction, the cell loses its flagella, grows, and transforms into a resting cyst by secreting an extra protective wall within which mitosis occurs (Fig. 8.6.). This stage is represented by the Dictyosphaera macroreticulata 
morphotype. The asexual cyst has no true ornamentation (processes) but only wall sculpture (reticulation) and it may settle immediately on to the bottom sediment and rest there during mitosis. An extant analogue is Chlamydomonas reinhardii, whose mother-cell wall swells after losing its flagella (e.g., Cavalier-Smith, 1974). In other chlorophyte species, asexual reproduction produces aplanospores, which differ in wall composition from their parent and do not possess flagella (Lee, 2008). Daughter cells are released through a rounded or split excystment structure. Asexual reproduction can continue unless the gametes fuse into another zygotic cyst and begin the sexual cycle.

Apart from the Dictyosphaera-Shuiyousphaeridium plexus, the newly recognized taxon Gigantosphaeridium has a sufficiently robust, large, acanthomorphic vesicle to substantiate a eukaryotic affinity, and it too probably had a complex life cycle with sexual reproduction and cyst formation.

Across the lineage Viridiplantae (including algae and plants), alternation between sexual and asexual reproductive strategies (heterogamy) is mostly dependent on environmental conditions (Lewontin, 1958; Bateman and DiMichele, 1994., Kaltz and Bell, 2002). In a stable, nutrient-rich environment, cells can simply divide asexually. However, under unfavorable conditions, sexual reproduction and genetic exchange are more beneficial and cells that combine to form a zygocyst will produce more viable offspring, despite the metabolically costly process of cyst formation. Life cycles with alternating generations are present in classes of extant microalgae (Chlorophytes, Charophytes). Similar patterns of cyst-like morphologies associated with resistant walls with complex structures are recognizable throughout the Viridiplantae.

\section{Biological affinity of Dictyosphaera- Shuiyousphaeridium plexus}

Review of previous hypotheses.-The biological affinities of organic-walled microfossils have long been a matter of discussion on the evolutionary history of early microbiota. Term acritarchs, which was applied to such organisms in referring to their uncertain origins, is now somewhat misleading because many of these microfossils have been progressively allocated to specific groupings, mainly eukaryotic phytoplankton (Tappan, 1980; Moczydłowska, 1991, 2011; Colbath and Grenfell, 1995; Arouri et al., 1999, 2000; Talyzina and Moczydłowska, 2000; Wicander, 2002; Grey, 2005; Traverse, 2007; Molyneux, 2009; Kaźmierczak and Kremer, 2009; Moczydłowska et al., 2011). There are exceptions, such as microfossil Tianzhushania identified as a metazoan embryo (Xiao et al., 1998; Yin et al., 2004, 2007) or a holozoan protist (Huldtgren et al., 2011; Bengtson et al., 2012), and "Tappania" from the Wynniatt Formation as a fungus (Butterfield, 2005, 2009; Javaux 2007). Some unidentified Ediacaran taxa, together with Alicesphaeridium and Gyalosphaeridium, were claimed to be potential diapause egg cysts (Cohen et al., 2009), based on morphology but lacking the evidence of cell division (Moczydłowska et al., 2011).

New observations and inferences on the DictyosphaeraShuiyousphaeridium plexus allow further comparisons with modern biota. Although their complete systematic position is difficult to establish due to scarce characters, their affinity can be narrowed down. These microfossils have been assigned to phytoplankton (Yin, 1997), undetermined green algae (Kaufman and Xiao, 2003), photosynthetic eukaryotes (Yin et al., 2005) and more specifically dinoflagellates (Meng et al., 2005; Yin and Yuan, 2007), or broadly identified as protists without distinguishing between auto- or heterotrophic modes of life (Javaux et al., 2003, 2004; Knoll et al., 2006). In contrast, Shuiyousphaeridium was considered as a possible fungus and heterotrophic, benthic, multicellular organism (Butterfield, 2005). Recently, it has been interpreted as a chlorophyte (Moczydłowska et al., 2011). Paleoecological conditions and the distribution of the microfossils studied in shallow marine facies point to a planktic life mode.

Kaufmann and Xiao (2003) inferred that Dictyosphaera was a photosynthetic alga since the organic carbon isotopic fractionation values $\left(\partial^{13} \mathrm{C}\right)$ obtained from the microfossil wall are consistent with primary productivity via the Calvin cycle of carbon fixation. This interpretation was accepted with reservations by Butterfield (2005), through his interpretation of the microfossil as a fungal ascocarp, but without an alternative explanation of the light carbon isotopic ratio in Dictyosphaera. A photosynthetic interpretation was also questioned by Javaux and Marshal (2006) on the grounds of "negative evidence" because of a lack of other diagnostic algal features, such as TLS in the wall or the presence of the biopolymer algaenan, rather than an evaluation of the isotopic signature significance. TLS and algaenan are not the only features diagnostic of algae, neither all algae possess them nor in all life stages. Inferences of a photosynthetic metabolism (Kaufman and Xiao, 2003; Meng et al., 2005) are supported by the phenotypic similarity of the microfossils to extant photosynthesizing protists, which remains the strongest indication of microfossils' metabolism.

The classification of Shuiyousphaeridium within dinoflagellates (Meng et al., 2005) remains dubious. Morphologically, the polygonal pattern of wall sculpture in the DictyosphaeraShuiyousphaeridium plexus is not comparable to the paratabulation of dinocysts (Moczydłowska et al., 2011) and, therefore, does not support a dinoflagellate affinity. There is a long time gap between the age of these microfossils and the estimated chronology of secondary and tertiary endosymbioses leading to the origin of derived microalgal classes, such as Mesozoic dinoflagellates (Fensome et al., 1996; Delwiche, 2007). Microfossils and dinocysts share some morphological features, but they are probably symplesiomorphic in dinoflagellates and inherited from symbiont(s) (Moczydłowska, 2010; Moczydłowska et al., 2011).

The main argument for dinoflagellate affinity came from the identification of the biopolymer dinosterane in the Shuiyousphaeridium cell wall (Meng et al., 2005). This molecule might have been derived from a dinoflagellate ancestor (Moczydłowska, 2010), or from another chromalveolate algae. The same compound family of dinosteranes was found in diatoms (stramenopiles) and prymnesiophytes (Volkman et al., 1993, 1998) - likewise derived and relatively recently evolved microalgae (Kooistra et al., 2007; Mustafa et al., 2009). Later organisms may retain the ability to synthesize steranes from a common precursor (Moldowan et al., 2001). The name dinosterane was coined because 
Table 1. Distribution of Dictyosphaera-Shuiyousphaeridium characters among protists.

\begin{tabular}{|c|c|c|c|c|c|c|c|c|}
\hline \multirow[b]{2}{*}{ Characters } & \multirow[b]{2}{*}{ Chlorophytes } & \multirow[b]{2}{*}{ Dinoflagellates } & \multirow[b]{2}{*}{ Charophytes } & \multirow[b]{2}{*}{ Fungi } & \multirow[b]{2}{*}{ Ciliates } & \multicolumn{3}{|c|}{ Amoebozoans } \\
\hline & & & & & & $\begin{array}{c}\text { Melicerion } \\
\text { poikilon }\end{array}$ & $\begin{array}{c}\text { Theratromyxa } \\
\text { webberi }\end{array}$ & Gromia sphaerica \\
\hline Reticulate wall morphology & + & + & - & + & + & + & + & $\begin{array}{l}\text { "Honeycomb } \\
\text { membrane" }\end{array}$ \\
\hline Multilayered wall & + & + & - & - & - & - & + & + \\
\hline $\begin{array}{l}\text { Acetolysis resistance } \\
\text { property }\end{array}$ & + & + & $\mathrm{n} / \mathrm{a}$ & - & $\mathrm{n} / \mathrm{a}$ & $\mathrm{n} / \mathrm{a}$ & - & - \\
\hline Cyst/spore formation & + & + & + & + & + & $\mathrm{n} / \mathrm{a}$ & Resting cyst & Resting cyst \\
\hline processes & + & + & + & $\begin{array}{l}\text { Process-like } \\
\text { extensions }\end{array}$ & - & - & - & - \\
\hline Excystment structures & + & + & - & - & $\mathrm{n} / \mathrm{a}$ & Oral opening & - & Oral capsule sheath \\
\hline Complex life cycle & + & + & + & + & + & $\mathrm{n} / \mathrm{a}$ & + & + \\
\hline Alternation of generations & + & + & + & + & + & $\mathrm{n} / \mathrm{a}$ & $\mathrm{n} / \mathrm{a}$ & + \\
\hline $\begin{array}{l}\text { Undisputed Precambrian } \\
\text { fossil record }\end{array}$ & + & - & - & Single occurrence & + & + & - & - \\
\hline
\end{tabular}

$4 \alpha$-methyl-24-ethylcolestane compounds were originally described from dinoflagellates in Black Sea sediments (Boon et al., 1979). It is now ambiguous as it is not restricted only to dinoflagellates. This could explain the presence of dinosteranes in sediment bulk samples from Archaean (Brocks et al., 2003), Proterozoic, and Cambrian ages (Summons et al., 1992; Peng et al., 1998; Moldowan and Talyzina, 1998; Moldowan et al., 2001; Knoll et al., 2007), well before the appearance of dinoflagellates in the Permian-Mesozoic rock record (Fensome et al., 1996). If resistant dinosteranes were derived from dinocysts, fossils would have been preserved; therefore the absence of dinocysts is less likely to be due to their poor preservation potential. While the biochemical pathway for dinosterane synthesis existed, the source may have been independent of dinoflagellates (Volkman, 2005).

Shuiyousphaeridium, and by default Dictyosphaera as its conspecific taxon, have also been compared to fungi (Butterfield, 2005). The author posited that the reticulate wall pattern corresponds to polygonal cells that form the multicellular ascocarp in primitive marine fungi (Pyreromycetae), while the processes in Shuiyousphaeridium are hyphae-like and the median-split represents a dehiscence structure that releases its spores. As has been shown in SEM images (Javaux et al., 2004; Meng et al., 2005), the reticulate sculpture is an integral part of the wall structure, here recognized as a primary wall (Fig. 7), and not a bundle or sheet of cells in a multicellular organism. Shuiyousphaeridium (and similarly the true Tappania morphotype) extracted repeatedly by palynological methods from the Ruyang Group (Yin and Yuan, 2007; Li et al., 2012; herein) did not demonstrate the presence of true septae within the processes. An additional reservation to postulating fungal affinity is that early fungi do not produce a resistant wall of such structural complexity (Elsik, 1996; Kalgutkar and Jansonius, 2000; Webster and Weber, 2007; Kalgutkar and Braman, 2008; Moczydłowska et al., 2011). Processes and excystment structures do not exist in fungi; fungal spores may have a pore or slit, with distinct appearance.

Innovations in the form of more complex morphology and the synthesis of resistant tissue in fungi arose later in their evolution, in terrestrial environments through adaptive opportunistic radiations following mass extinctions in the Mesozoic (Vajda and McLaughlin, 2004) and through their co-evolution with angiosperms (Elsik, 1996; Traverse, 2007; Kalgutkar and
Braman, 2008). Acetolysis-resistant vesicle of DictyosphaeraShuiyousphaeridium consists of a suite of features that suggest affinities to cyst-producing taxa among extant photosynthetic protists.

Comparison with other protists.-The layered wall with platelets located on the internal side in DictyosphaeraShuiyousphaeridium plexus has no comparison, to our knowledge, to any heterotrophic protists, which also differ in having only external scale wall elements, polar symmetry, an oral opening, and generally do not produce a secondary wall (Table 1). They may occasionally produce a wall with mineralized scales (test) that is potentially preservable, as observed in testate amoebozoans recognized in Neoproterozoic at c. 770 $740 \mathrm{Ma}$ (Porter, 2006), initially called the vase-shaped microfossils (Bloeser et al., 1977). They show a well-defined oral opening for exuding cytoplasm, often with a plug. The test is rigid, composed of acetolysis-resistant organic matter, and may show a reticulate surface pattern of once attached scales (Melicerion poikilon). These microfossils have been recognized as heterotrophic biota since their discovery (Bloeser, 1985; Marti-Mus and Moczydłowska, 2000; Porter and Knoll, 2000; Porter et al., 2003; Porter, 2006).

Superficial morphological resemblances to DictyosphaeraShuiyousphaeridium are further found in ventral polygonal bulges of the ciliate Codonella cratera (Duff et al., 2008), and honeycomb membrane of the thecamoeba Gromia sphaerica (Gooday et al., 2000) (Table 1). Sporophytes of red algae also share this appearance, but are much larger in size.

Among autotrophic protists other than green algae, a cell wall with organic and biomineralized scales or plate-like elements in the wall structure is known in haptophytes and chrysophytes, and is exclusively an external covering of vegetative cells and cysts. Haptophytes possess organic scales on the surface of the flagellate cell and calcitic coccoliths in the nonmotile stage (coccolithophorids) and their record is restricted to the last $200 \mathrm{Ma}$ (Read et al., 2013). Chrysophytes produce mineralized cysts, but their vegetative cells are covered with silicified scales and spines, solely on the cell surface. Silicoflagellates produce a lattice-like siliceous internal skeleton, but they are no older than the Cretaceous (McCartney, 1993). 
The earliest record of biomineralized scale microfossils (composed of apatite and organic carbon) is in cherts of the Neoproterozoic Tindir Group, Canada, (Allison and Hilgert, 1986; Cohen et al., 2011). They were identified as a putative green alga, although they resemble the cell-covering scales of various extant algal groups like prasinophytes, chrysophytes, haptophytes, and streptophytes, as well as heterotrophic ciliates and testate amoebans (Cohen et al., 2011).

We argue that the microfossils studied here do not belong in any of these groups because of a primary diagnostic featurethe acetolysis-resistant cell wall, which in a combination with the morphologic and cell-wall structural features recorded here are only found in the phenotype of green microalgae. Even more significantly, multi-layered walls are features known only in extant prasinophytes, chlorophytes, charophytes and dinoflagellates. All these green algal lineages derived from an ancestral monophyletic lineage evolved by primary symbiosis (O'Kelly, 2007), making Dictyosphaera-Shuiyousphaeridium a candidate for this group. Resistant cell walls are typical of so-called "plant cells" produced by algae and vascular plants (Raven et al., 2005) and are recognized among unicellular organic-walled microfossils of various ages since ca. $1.8 \mathrm{Ga}$ through the Phanerozoic (Moczydłowska et al., 2011).

In conclusion, the Dictyosphaera-Shuiyousphaeridium plexus has little to suggest it belongs in the dinocysts or heterotrophic protists or fungi (Table 1).

Present interpretation.-As discussed above, the available evidence points towards Dictyosphaera-Shuiyousphaeridium being cysts of photosynthetic protists belonging to the green microalgae Chloroplastida (=Viridiplantae), following the eukaryotic phylogeny model of Baldauf (2008). Alternatively, they represent an ancestral lineage of photosynthetic protists of the supergroup Bikonta before divergence into the Viridiplantae and Chromalveolata lineages, following the phylogenetic tree of Cavalier-Smith (2003, 2004, 2010). Microfossils studied here share general morphological characters with green algae and chromalveolates, such as zygotic cyst-like vesicles with processes and excystment structures, structurally complex walls, as well as being photosynthetic. The resistant biopolymers in their walls are consistent with photosynthesizing biota (Moczydłowska and Willman, 2009). Yet due to more recent evolution of Chromalveolata (Archibald and Keeling, 2004; Yoon et al., 2004), these characters could be ancestral (plesiomorphic) and deriving from primary endosymbiotic green eukaryote and their position in Viridiplantae is more likely.

Acanthomorphic vesicles with lavish processes are characteristic of reproductive cysts and found in many extant microalgal species. Examples are provided by chlorophytes Golenkinia radiata (Chlorococcales; Chodat, 1894; Guiry and Guiry, 2013), and Atractomorpha echinata (Sphaeropleales; Hoffman, 1983), charophytes Micrasterias papillifera (Kies, 1970), Micrasterias thomasiana (Blackburn and Tyler, 1981), and Staurastrum furgicerum (Lacalli, 1981). Distally divided processes in Shuiyousphaeridium resemble the processes in these algal zygocysts. Different fibrilar and occasionally looped processes of Gigantosphaeridium fibratum n. gen. et sp., bear similarities to extant marine microalgae Sphaeropsis (Pterospermataceae, Chlorophyta) and Piropsis (Craspedophyta) from the North Sea and Arctic Sea (AlgaeBASE). Secondary wall synthesis during the cyst stage was observed in several extant taxa: chlorophyte Haematococcus pluvialis (Hagen et al., 2002; Damiani et al., 2006) and charophyte M. thomasiana (Blackburn and Tyler, 1981), Volvocales (Hagen et al., 2002), resembling features in the studied taxa.

Our reconstruction of the Dictyosphaera-Shuiyousphaeridium life cycle based on the alternation of sexual and asexual generations is a common model of reproductive strategy across extant lineages of Viridiplantae, Chromalveolata, Fungi, and Amoebozoa (Table 1), indicating either an ancestral character derived from the last eukaryotic common ancestor (LECA) or independent evolution postdating the split of major eukaryotic groups. The latter alternative could be understood as a method of coping with adverse conditions in different clades (Lewontin, 1957; 1958).

Considering the sequence of phylogenetic divergences within the lineage Chloroplastida, which also reflects ecological adaptations from marine to fresh water environments and colonization of terrestrial realm, the Charophytes and land plants are derived and later evolved lineages (Paleozoic; Graham and Gray, 2001; Wellman et al., 2003; O'Kelly, 2007; Rubinstein et al., 2010) than primary lineages of Prasinophytes and Chlorophytes (Turmel et al., 2002, 2008; Raven et al., 2005; Baldauf, 2008). Prasinophytes are known to reproduce asexually and, although producing protective cysts, they lack superficial processes. Chlorophytes reproduce asexually and sexually, forming protective cysts of high disparity.

In sum, the Dictyosphaera-Shuiyousphaeridium organism is inferred to be microalga in the lineage Chloroplastida of the group Archaeplastida, following the phylogeny of Baldauf (2003, 2008). Chloroplastida (green algae and land plants) has been recognized by Adl et al. (2005) and previously classified in a rank of the kingdom Viridiplantae (Cavalier-Smith, 1981).

The phylogenetic position of Shuiyousphaeridium has been suggested within the Viridiplantae and the early branch of chlorophytes (Moczydłowska et al., 2011). We may confirm the position of the Dictyosphaera-Shuiyousphaeridium organism in the stem lineage of Chloroplastida by present study of the wall structure and further conclusions on the functional biology.

\section{Intracellular complexity and innovation of the secondary wall}

Characteristic eukaryotic organelles, including a nucleus and the Golgi apparatus (GA), together with a cytoskeleton, and complex sterol-containing membranes, are considered to have been acquired at the time of "cryptic prehistory" prior to c. $2.1 \mathrm{Ga}$ (Runnegar, 1994). Intracellular complexity defining eukaryotic origin and early cellular differentiation in Proterozoic fossils has been noted by Butterfield (2000) and Knoll et al., (2006) with respect to three cell types of gametophytic Bangiomorpha and potential requirement for a cytoskeleton and cell shape regulation in Tappania, Shuiyousphaeridium and Germinosphaera.

Eukaryotic affinity of the Dictyosphaera-Shuiyousphaeridium organism and phylogenetic position in Chloroplastida is supported by its remarkable wall structure and the innovation of a secondary wall, thus requiring a degree of intracellular complexity for its 
synthesis. The advanced level of organization of a eukaryotic cell with endomembrane system, ER and the GA, cytoskeleton, organelles including mitochondrion, plastid and machinery for sexual reproduction is inferred for these microfossils. The organelles thought to be present in early eukaryotes, primarily nucleus and mitochondrion, and structures providing the minimum requirement for eukaryotic cell functioning, i.e., endomembrane system and cytoskeleton (Stanier, 1970; Lang et al., 1999; Cavalier-Smith, 2003, 2010; Dacks and Field, 2004; ) have been inferred to exist in some Mesoproterozoic taxa, such as Tappania, Valeria, and Shuiyousphaeridium (Javaux et al., 2001, 2003, 2004).

Accepting the hypothesis of the photosynthetic metabolism of Dictyosphaera- Shuiyousphaeridium (Kaufman and Xiao, 2003; Meng et al., 2005; Moczydłowska et al., 2011), we consequently suggest the presence of a plastid, ostensibly chloroplast.

In the Dictyosphaera-Shuiyousphaeridium organism we can interpret the controlled secretion and arrangement of polygonal organic platelets building a secondary cell wall and playing a role in cyst formation. Wall elements could have been formed and secreted through the GA and the endoplasmic reticulum (ER), major biosynthesis organelles found in most eukaryotes and all plants.

The organic platelets reinforcing the cell wall conform to the reticulation of the primary wall (Fig. 7). Such a pattern of wall construction is known in extant eukaryotes, whereby the GA and the ER secrete organic granules that become subsequently attached to the cell membrane. Such process occurs in the extant alga Nephroselmis olivacea (Suda et al., 2004). The GA and the ER are also crucial for cell wall formation in Chrysophyceae (Brown, 1969), and wall scales formation in Scherffelia dubia (McFadden et al., 1986) and other Prasinophyceae (Melkonian et al., 1991). They produce complex sugars and polysaccharides (Dupree and Sherrier, 1998; Goubet et al., 2009) that may explain the resistant property of the vesicle wall. Cell wall secretion is mediated by GA in chlorophyte Micrasterias (Meindl, 1993; Lütz-Meindl and Broch-Salomon, 2000) resulting in an ornamented cell shape, and in the formation of retaining wall conjoining the cells of colonial Botryococcus braunii (Weiss et al., 2012).

As discussed above, the secondary wall is a significant feature of the Dictyosphaera-Shuiyousphaeridium cysts. Protistan cell wall fulfills three roles: 1) defense against bacterial biodegradation, phagocythosis and (micro)predation; 2) survival under unfavorable environmental conditions; 3) protection during reproduction. The last function may be combined with the other two, as the developing offspring would require protection against both heterotrophy and adverse conditions. All these factors might have driven the evolution of more complex eukaryotic cyst walls in the Mesoproterozoic. Environmentally induced light intensity, local nutrient supply, temperature changes, anoxia, and access to metabolically important metals (Anbar and Knoll, 2002; Klein et al., 1992; Lee, 2008; Parnell et al., 2012) could have driven the development of reproductive and resting stages. While the first true signs of micropredation (Porter et al., 2003) and biomineralized defense structures (Cohen et al., 2011) do not appear in the fossil record until Neoproterozoic, it is reasonable to assume that the first step in protection of early photosynthetic eukaryotes would have been the composite reinforcement of the organic cell wall, i.e. the evolution of a secondary wall as observed in the Dictyosphaera-Shuiyousphaeridium organism.

\section{Conclusions}

Unicellular organic-walled microfossils were recovered from the shallow marine shales of 1.7-1.2 Ga Beidajian Formation, Ruyang Group in northern China. They include ornamented morphotypes Dictyosphaera macroreticulata Xing and Liu, 1973, Shuiyousphaeridium macroreticulatum Yan, 1992, emended, and a new genus and species Gigantosphaeridium fibratum, which is among the largest known microfossils in Mesoproterozoic. Identical wall reticulation patterns and wall structures occur in two taxa, Dictyosphaera and Shuiyousphaeridium and appear to represent a single biological species and its cysts in heteromorphic life-cycle generations. Dictyosphaera is an asexual (resting) cyst and Shuiyousphaeridium is a sexual (zygotic) one, as can be inferred by comparing their phenotypic features and functional morphology to those of extant photosynthesizing microbiota. The simplest explanation for this is that the fossils represent haploid and diploid stages, and have a reproductive strategy of alternation between the asexual mitotic division into clonal daughter cells and sexual meiotic division from a zygote.

The large size, robust body and lavish ornamentation of Gigantosphaeridium gen. n., demonstrates not only eukaryotic affinity but also the reproductive function.

Dictyosphaera and Shuiyousphaeridium illustrate the evolution of complexity in cyst- wall structure and provide the earliest record so far of a secondary wall composed of polygonal platelets. The metabolic expenditure required to construct complex, resistant walls paid off in terms of increased protection during cell division. The construction of a protective cyst suggests that a sexual reproductive stage was already established by the end of the Mesoproterozoic.

Intricate walls would require well-developed intracellular machinery for their production and for maintenance of large cells, such as that found in extant algae where organic components are secreted by the Golgi apparatus, transported through the endoplasmatic reticulum and integrated into the cell membrane. Indirect evidence for Golgi apparatus activity and the presence of endoplasmatic reticulum is provided by infilling of the primary wall by crude platelets. Accepting a photosynthetic mode of life, the plastids were also among the organelles of this early eukaryote.

The combination of several lines of evidence based on morphology, cell wall ultrastructure, and biochemistry, and comparisons with extant microbiota provides compelling argument that Mesoproterozoic Dictyosphaera-Shuiyousphaeridium microorganism belongs among the photosynthetic eukaryotes of the stem group Chloroplastida, as part of the lineage of modern eukaryotic phytoplankton.

\section{Acknowledgments}

Funding from the Swedish Research Council (Vetenskapsrådet, VR) through research grant no. 621-2009-4445 to M. Moczydłowska is acknowledged. The study is a part of a Ph.D. project by H. Agić. Research by L. Yin was financially supported by the National Natural Science Foundation of China, Grants No. 40839910 and 41173051. We thank K. Grey (Geological Survey of Western Australia) for her comments and aid in editing the manuscript. We also acknowledge comments by 
N. Butterfield (University of Cambridge). The editors have been very helpful in providing constructive remarks. G. Wife (EBC, Uppsala University) is acknowledged for his assistance in preparing the material for SEM.

\section{Accessibility of supplemental data}

Supplemental materials deposited at Dryad: doi:10.5061/ dryad.80rb8

\section{References}

Adl, S.M., Simpson, A.G.B., Farmer, M.A., Andersen, R.A., Anderson, O.R., Barta, J.R., Bowser, S.S., Brugerolle, G., Fensome, R.A., Fredericq, S., James, T.Y., Karpov, S., Kugrens, P., Krug, J., et al., 2005, The new higher level classification of eukaryotes with emphasis on the taxonomy of protists: Journal of Eukaryotic Microbiology, v. 52, p. 399-451, doi: 10.1111/ j.1550-7408.2005.00053.x.

Allison, C.W., and Hilgert, J.W., 1986, Scale microfossils from the Early Cambrian of north-west Canada: Journal of Paleontology, v. 60, p. 973-1015.

Anbar, A.D., and Knoll, A.H., 2002, Proterozoic Ocean chemistry and evolution: a bioinorganic bridge?: Science, v. 297, p. 1137-1142, doi: 10.1126/ science. 1069651 .

Archibald, J.M., and Keeling, P.J., 2002, Recycled plastids: a "green movement" in eukaryotic evolution: Trends in Genetics, v. 18, p. 577-584, doi: $10.1016 / \mathrm{S} 0168-9525(02) 02777-4$

Archibald, J.M., and Keeling, P.J., 2004, The evolutionary history of plastids: a molecular phylogenetic perspective, in Hirt, R.P. and Horner, D.S. eds., Organelles, Genomes, and Eukaryote Phylogeny: an Evolutionary Synthesis in the Age of Genomics, Systematics Association Special Volume, Boca Raton, CRS Press, p. 55-74.

Arouri, K., Greenwood, P.F., and Walter, M.R., 1999, A possible chlorophycean affinity of some Neoproterozoic acritarchs: Organic Geochemistry, v. 30, p. 1323-1337, doi: 10.1016/S0146-6380(99)00105-9.

Arouri, K., Greenwood, P.F., and Walter, M.R., 2000, Biological affinities of Neoproterozoic acritarchs from Australia: microscopic and chemical characterisation: Organic Geochemistry, v. 31, p. 75-89.

Baldauf, S.L., 2008, An overview of the phylogeny and diversity of eukaryotes: Journal of Systematics and Evolution, v. 46, p. 263-273, doi: 10.3724/SP. J.1002.2008.08060.

Baldauf, S.L., 2003, The Deep roots of eukaryotes: Science, v. 300, p. $1703-$ 1706, doi: $10.1126 /$ science. 1085544.

Barghoorn, E.S., and Tyler, S.A., 1965, Microorganisms from the Gunflint Chert: These structurally preserved Precambrian fossils from Ontario are the most ancient organisms known: Science, v. 147, p. 563-575, doi: 10.1126/ science.147.3658.563.

Bateman, R.M., and DiMichele, W.A., 1994, Heterospory: the most key innovation in the evolutionary history of the plant kingdom: Biological Reviews, v. 69 , p. 345-417, doi: 10.1111/j.1469-185X.1994.tb01276.x.

Bateman, R.M., and Dimichele, W.A., 1994, Heterospory - the most key innovation in the evolutionary history of the plant kingdom: Botanical Reviews of the Cambridge Philosophical Society, v. v.69, p 315-417.

Belmonte, G., Miglietta, A., Rubino, F., and Boero, F., 1997, Morphological convergence of resting stages of planktonic organisms: a review: Hydrobiologia, v. 355, p. 159-165, doi: 10.1023/A:1003071205424.

Bengtson, S., Cunningham, J.A., Yin, C., and Donoghue, P.C.J., 2012, A merciful death for the "earliest bilaterian," Vernanimalcula: Evolution \& Development, v. 14, p. 421-427, doi: 10.1111/j.1525-142X.2012.00562.x.

Bhattacharya, D., Yoon, H.S., Hedges, S.B., and Hackett, J.D., 2009, Eukaryotes, in Hedges, S.B., and Kumar, S., eds. The Timetree of Life Oxford University Press, p 116-120.

Blackburn, S.I., and Tyler, P.A., 1981, Sexual reproduction in desmids with special reference to Micrasterias thomasiana var. notata (Nordst.): Grönblad: British Phycological Journal, v. v. 16, p 217-29.

Bloeser, B., 1985, Melanocyrillium, a new genus of structurally complex late Proterozoic microfossils from the Kwagunt Formation (Chuar Group), Grand Canyon, Arizona: Journal of Paleontology, v. 59, p. 741-765.

Bloeser, B., Schopf, J.W., Horodyski, R.J., and Breed, W.J.., 1977. Chitinozoans from the Late Precambrian Chuar Group of the Grand Canyon: Arizona, Science v. 195, p 676-679.

Bold, H.C., and Wynne, M.J., 1985. Introduction to the Algae Prentice Hall, Inc. New Jersey 720 p.

Boon, J.J., Rijpstra, W.I.C., De Lange, F., De Leeuw, J.W., Yoshioka, M., and Shimizu, Y., 1979, Black Sea sterol-a molecular fossil for dinoflagellate blooms: Nature, v. 277, p. 125-127, doi: 10.1038/277125a0.
Brasier, M.D., and Lindsay, J.F., 1998, A billion years of environmental stability and the emergence of eukaryotes: New data from northern Australia: Geology, v. 26, p. 555-558, doi: 10.1130/0091-7613(1998)026<0555: ABYOES > 2.3.CO;2.

Brocks, J.J., Buick, R., Summons, R.E., and Logan, G.A., 2003, A reconstruction of Archaean biological diversity based on molecular fossils from the 2.78 - 2.45 billion years old Mount Bruce Supergroup, Hamersley Basin, Western Australia: Geochimica et Cosmochimica Acta, v. 67, p. $4321-4335$.

Brown, R.M., 1969, Observations on the relationship of the Golgi apparatus to wall formation in the marine chrysophycean alga, Pleurochrysis scherffelii Pringsheim: Journal of Cell Biology, v. 41, p. 109-123.

Butterfield, N.J., 2004, A vaucheriacean alga from the middle Neoproterozoic of Spitsbergen: implications for the evolution of Proterozoic eukaryotes and the Cambrian explosion: Paleobiology, v. 30, p. 231-252, doi: 10.1666 /0094-8373(2004)030<0231:AVAFTM > 2.0.CO;2.

Butterfield, N.J., 2000, Bangiomorpha pubescens n. gen., n. sp.: implications for the evolution of sex, multicellularity, and the Mesoproterozoic/Neoproterozoic radiation of eukaryotes: Paleobiology, v. 26, p. 386-404, doi: 10.1666/0094-8373(2000)026 < 0386:BPNGNS > 2.0.CO;2.

Butterfield, N.J., 2009, Modes of pre-Ediacaran multicellularity: World Summit on Ancient Microscopic Fossils, v. 173, p. 201-211, doi: 10.1016/j. precamres.2009.01.008.

Butterfield, N.J., 2005, Probable Proterozoic fungi: Paleobiology, v. 31, p. $165-182$, doi: $10.1666 / 0094-8373(2005) 031<0165$ :PPF $>2.0 . C O ; 2$.

Cavalier-Smith, T., 1974, Basal body and flagellar development during the vegetative cell cycle and the sexual cycle of Chlamydomonas reinhardii: Journal of Cell Science, v. 16, p. 529-556.

Cavalier-Smith, T., 1981, Eukaryote kingdoms: seven or nine?: Biosystems, v. v. $14, \mathrm{p} 461-481$.

Cavalier-Smith, T., 2006, Cell evolution and Earth history: stasis and revolution: Philosophical Transactions of the Royal Society B: Biological Sciences, v. 361, p. 969-1006, doi: 10.1098/rstb.2006.1842.

Cavalier-Smith, T., 2004, Only six kingdoms of life: Proceedings of the Royal Society of London. Series B: Biological Sciences, v. 271, p. 1251-1262, doi: $10.1098 / \mathrm{rspb} .2004 .2705$.

Cavalier-Smith, T., 2010, Origin of the cell nucleus, mitosis and sex: roles of intracellular coevolution: Biology Direct, v. 5, p. 7-78, doi: 10.1186/ 1745-6150-5-7.

Cavalier-Smith, T., 2003, Protist phylogeny and the high-level classification of Protozoa: European Journal of Protistology, v. 39, p. 338-348, doi: 10.1078/0932-4739-00002.

Chen, J.B., Zhang, H.M., Zhu, S.X., Zhao, Z., and Wang, Z., 1980, Research on Sinian Suberathem of Jixian, Tianjin, in Proceedings of a Conference on Research on Precambrian Geology; Sinian Suberathem in China, China, Tianjin Science and Technology Press, p. 56-114.

Chodat, R., 1894, Golenkinia, genre nouveau de Protococcoidées: Journal de Botanique, v. 18, p. 305-309.

Cohen, P.A., Knoll, A.H., and Kodner, R.B., 2009, Large spinose microfossils in Ediacaran rocks as resting stages of early animals: Proceedings of the National Academy of Sciences, v. v. 106, p 6519-6524.

Cohen, P.A., Schopf, J.W., Butterfield, N.J., Kudryavtsev, A.B., and Macdonald, F.A., 2011, Phosphate biomineralization in mid-Neoproterozoic protists: Geology, v. 39, p. 539-542, doi: 10.1130/G31833.1.

Colbath, G.K., and Grenfell, H.R., 1995, Review of biological affinities of Paleozoic acid-resistant, organic-walled eukaryotic algal microfossils (including "acritarchs"): Review of Palaeobotany and Palynology, v. 86, p. 287-314, doi: 10.1016/0034-6667(94)00148-D.

Dacks, J.B., and Field, M.C., 2004, Eukaryotic cell evolution from a comparative genomic perspective: the endomembrane system, in Hirt, R.P. and Horner, D.S. eds., Organelles, genomes and eukaryote phylogeny: an evolutionary synthesis in the age of genomics, Systematics Association Special Volume Series, Boca Raton, p. 309-334.

Dale, B., 1983, Dinoflagellate resting cysts: "benthic plankton," in Fryxell, G.A. ed., Survival Strategies of the Algae, p. 69-136.

Dale, B., 2001, The sedimentary record of dinoflagellate cysts: looking back into the future of phytoplankton blooms: Scientia Marina, v. 65, p. 257-272, doi: 10.3989/scimar.2001.65s2257.

Damiani, M.C., Leonardi, P.I., Pieroni, O.I., and Cáceres, E.J., 2006, Ultrastructure of the cyst wall of Haematococcus pluvialis (Chlorophyceae): wall development and behaviour during cyst germination: Phycologia, v. 45, p. 616-623, doi: 10.2216/05-27.1.

Delwiche, C.F., 2007, The origin and evolution of dinoflagellates, in Falowski, P. and Knoll, A. eds., Evolution of Primary Producers in the Sea, Elsevier Academic Press, p. 193-205.

Duff, R.J., Ball, H., and Lavrentyev, P.J., 2008, Application of combined morphological-molecular approaches to the identification of planktonic protists from environmental samples: Journal of Eukaryotic Microbiology, v. v. 55, p $306-312$. 
Dupree, P., and Sherrier, D.J., 1998, The plant Golgi Apparatus: Biochimica et Biophysica Acta (BBA) - Molecular Cell Research, v. 1404, p. 259-270, doi: 10.1016/S0167-4889(98)00061-5.

Elsik, W.C., 1996, Fungi, in Jansonius, J. and McGregor, D.C. eds., Palynology: Principles and Applications, Texas, American Association of Stratigraphic Palynologists Foundation, p. 293-306.

Evitt, W.R., 1985, Sporopollenin dinoflagellate cysts: their morphology and interpretation: Texas, American Association of Stratigraphic Palynologists Foundation, $333 \mathrm{p}$.

Fensome, R.A., 1990, Acritarchs and fossil prasinophytes: an index to genera, species and infraspecific taxa: American Association of Stratigraphic Palynologists, $771 \mathrm{p}$

Fensome, R.A., MacRae, R.A., Moldowan, J.M., Taylor, F.J.R., and Williams, G.L., 1996, The early Mesozoic radiation of dinoflagellates: Paleobiology, v. 22 , p. $329-338$.

Gooday, A.J., Bowser, S.S., Bett, B.J., and Smith, C.R., 2000, A large testate protist, Gromia sphaerica sp. nov. (Order Filosea), from the bathyal Arabian Sea: Deep Sea Researth Part II: Topical Studies in Oceanography, v. 47, p. 55-73.

Goubet, F., Barton, C.J., Mortimer, J.C., Yu, X., Zhang, Z., Miles, G.P., Richens, J., Liepman, A.H., Seffen, K., and Dupree, P., 2009, Cell wall glucomannan in Arabidopsis is synthesised by CSLA glycosyltransferases, and influences the progression of embryogenesis: The Plant Journal, v. 60, p. 527-538, doi: 10.1111/j.1365-313X.2009.03977.x.

Graham, L.E., and Gray, J., 2001, The origin, morphology, and ecophysiology of early embryophytes: neontological and paleontological perspectives, in Gensel, P.G. and Edwards, D. eds., Plants Invade the Land: Evolutionary and Environmental Perspectives, Critical Moments and Environmental Perspectives, New York, Columbia University Press, p. 140-158.

Graham, N.A., McClanahan, T.R., MacNeil, M.A., Wilson, S.K., Polunin, N.V., Jennings, S., Chabanet, P., Clark, S., Spalding, M.D., and Letourneur, Y., 2008, Climate warming, marine protected areas and the ocean-scale integrity of coral reef ecosystems: PLoS One, v. 3, p. e3039 doi: 10.1371/journal pone. 0003039 .

Graham, L.K.E., and Wilcox, L.W., 2000, The origin of alternation of generations in land plants: a focus on matrotrophy and hexose transport: Philosophical Transactions of the Royal Society of London. Series B: Biological Sciences, v. 355, p. 757-767, doi: 10.1098/rstb.2000.0614.

Grey, K., 2005, Ediacaran palynology of Australia: Association of Australasian Palaeontologists, $439 \mathrm{p}$

Guan, B., Geng, W., Rong, Z., and Du, H., 1988, The Middle and Upper Proterozoic in the northern slope of the eastern Qinling Ranges, Henan, China: Zhengzhou, China, Henan Science and Technology Press, 210 p.

Guiry, M.D., and Guiry, G.M., 2013, AlgaeBase: World-wide electronic publication, National University of Ireland, Galway: http://www.algaebase.org.

Hackett, J.D., Yoon, H.S., Butterfield, N.J., Sanderson, M.J., and Battacharya, D., 2007, The origin and evolution of dinoflagellates, in Falowski, P., and Knoll, A. eds., Evolution of Primary Producers in the Sea, Elsevier Academic Press, p. 109-132.

Hagen, C., Siegmund, S., and Braune, W., 2002, Ultrastructural and chemical changes in the cell wall of Haematococcus pluvialis (Volvocales, Chlorophyta) during aplanospore formation: European Journal of Phycology, v. 37, p. 217-226, doi: 10.1017/S0967026202003669.

Head, M.J., Lewis, J., and De Vernal, A., 2006, The cyst of the calcareous dinoflagellate Scrippsiella trifida: Resolving the fossil record of its organic wall with that of Alexandrium tamarense: Journal of Paleontology, v. 80, p. 1-18, doi: 10.1666/0022-3360(2006)080[0001:TCOTCD]2.0.CO;2.

Hoffman, H.J., 1971, Precambrian fossils, pseudofossils and problematica in Canada: Geological Survey of Canada Bulletin, v. 189, p. 1-146.

Hoffman, L.R., 1983, Male gametes of Atractomorpha echinata Hoffman (Chlorophyceae): Journal of Phycology, v. v. 20, p. 573-584.

Holland, H.D., 2006, The oxygenation of the atmosphere and oceans: Philosophical Transactions of the Royal Society B: Biological Sciences, v. 361, p. 903-915, doi: 10.1098/rstb.2006.1838.

$\mathrm{Hu}, \mathrm{Y}$., and Fu, J., 1982, Micropalaeoflora from the Gaoshanhe Formation of Late Precambrian of Luonan, Shaanxi and its stratigraphic significance: Bulletin of the Xi' an Institute of Geology and Mineral Resources, Chinese Academy of Geological Science, v. 4, p. 102-113.

Huldtgren, T., Cunningham, J.A., Yin, C., Stampanoni, M., Marone, F., Donoghue, P.C.J., and Bengtson, S., 2011, Fossilized nuclei and germination structures identify Ediacaran "animal embryos" as encysting protists: Science, v. 334, p. 1696-1699, doi: 10.1126/science.1209537.

Huntley, J.W., Xiao, S., and Kowalewski, M., 2006, 1.3 Billion years of acritarch history: An empirical morphospace approach: Precambrian Research, v. 144, p. 52-68, doi: 10.1016/j.precamres.2005.11.003.

Javaux, E.J., 2007, The early eukaryotic fossil record, in Jékely, G. ed., Eukaryotic membranes and cytoskeleton origins and evolution, New York, Landes Bioscience and Springer Science + Business Media, p. 1-19.
Javaux, E.J., Knoll, A.H., and Walter, M.R., 2001, Morphological and ecological complexity in early eukaryotic ecosystems: Nature, v. 412, p. 66-69, doi: $10.1038 / 35083562$.

Javaux, E., Knoll, A., and Walter, M.R., 2003, Recognizing and interpreting the fossils of early eukaryotes: Origins of Life and Evolution of the Biosphere, v. 33, p. 75-94, doi: 10.1023/A:1023992712071.

Javaux, E., Knoll, A., and Walter, M.R., 2004, TEM evidence for eukaryotic diversity in mid-Proterozoic oceans: Geobiology, v. 2, p. 121-132, doi: 10.1111/j.1472-4677.2004.00027.x.

Javaux, E.J., and Marshal, C.P., 2006, A new approach in deciphering early protist paleobiology and evolution: Combined microscopy and microchemistry of single Proterozoic acritarchs: Studies in Precambrian and Palaeozoic Palynology, v. 139, p. 1-15, doi: 10.1016/j.revpalbo.2006. 01.005 .

Kalgutkar, R.M., and Braman, D.R., 2008, Santonian to ?earliest Campanian (Late Cretaceous) fungi from the Milk River Formation, Southern Alberta, Canada: Palynology, v. 32, p. 39-61, doi: 10.1080/01916122. 2008.9989649.

Kalgutkar, R.M., and Jansonius, J., 2000, Synopsis of fossil fungal spores, mycelia and fructifications:

Kaltz, O., and Bell, G., 2002, The ecology and genetics of fitness in Chlamydomonas. XII. Repeated sexual episodes increase rates of adaptation to novel environments: Evolution, v. 56, p. 1743-1753, doi: 10.1111/j.00143820.2002.tb00188.x.

Kaufman, A.J., and Xiao, S., 2003, High $\mathrm{CO}_{2}$ levels in the Proterozoic atmosphere estimated from analyses of individual microfossils: Nature, $\mathrm{v}$. 425, p. 279-282, doi: 10.1038/nature01902.

Kaźmierczak, J., and Kremer, B., 2009, Spore-like bodies in some early paleozoic acritarchs: clues to chlorococcalean affinities: Acta Palaeontologica Polonica, v. 54, p. 541-551, doi: 10.4202/app.2008.0060.

Kempe, A., Schopf, J.W., Altermann, W., Kudryavtsev, A.B., and Heckl, W.M. 2002, Atomic force microscopy of Precambrian microscopic fossils: Proceedings of the National Academy of Sciences, v. 99, p. 9117-9120, doi: 10.1073/pnas.142310299.

Kempe, A., Wirth, R., Altermann, W., Stark, R.W., Schopf, J.W., and Heckl, W. M., 2005, Focussed ion beam preparation and in situ nanoscopic study of Precambrian acritarchs: Precambrian Research, v. 140, p. 36-54, doi: 10.1016/j.precamres.2005.07.002.

Kies, L., 1970, Elektronenmikroskopische Untersuchungen über Bildung und Struktur der Zygotenwald bei Micrasterias papillifera (Desmisiaceae) Protoplasma, v. 70, p. 21-47.

Klein, C., Beukes, N.J., Holland, H.D., Kasting, J.F., Kump, L.R., and Lowe, D.R., 1992, Proterozoic atmosphere and ocean, in Schopf, J.W. and Klein, C. eds., The Proterozoic Biosphere, Cambridge, Cambridge University Press.

Knoll, A., Javaux, E.., Hewitt, D., and Cohen, P., 2006, Eukaryotic organisms in Proterozoic oceans: Philosophical Transactions of the Royal Society B: Biological Sciences, v. 361, p. 1023-1038, doi: 10.1098/ rstb.2006.1843.

Knoll, A., Summons, R.E., Waldbauer, J.R., and Zumberge, J.E., 2007, The geological succession of primary producers in the oceans, in Falowski, P. and Knoll, A. eds., Evolution of Primary Producers in the Sea, Elsevier Academic Press, p. 133-163.

Kokinos, J.P., and Anderson, D.M., 1995, Morphological development of resting cysts in cultures of the marine dinoflagellate Lingulodinium polyedrum (= L. Machaerophorum): Palynology, v. 19, p. 143-166, doi: 10.1080/01916122.1995.9989457.

Kooistra, W.H.C.F., Gersonde, R., Medlin, L.K., and Mann, D.G., 2007, The origin and evolution of diatoms: their adaptation to a planktonic existence, in Falowski, P. and Knoll, A. eds., Evolution of Primary Producers in the Sea, Elsevier Academic Press, p. 133-163.

Lacalli, T.C., 1981, Dissipative structures and morphogenetic pattern in unicellular algae: Philosophical Transactions of the Royal Society of London. B, Biological Sciences, v. 294, p. 547-588, doi: 10.1098/rstb.1981.0118.

Lamb, D.M., Awramik, S.M., Chapman, D.J., and Zhu, S., 2009, Evidence for eukaryotic diversification in the $\sim 1800$ million-year-old Changzhougou Formation, North China: World Summit on Ancient Microscopic Fossils, v. 173, p. 93-104, doi: 10.1016/j.precamres.2009.05.005.

Lang, B.F., Gray, M.W., and Burger, G., 1999, Mitochondrial genome evolution and the origin of eukaryotes: Annual Review of Genetics, v. 33, p. 351-397, doi: 10.1146/annurev.genet.33.1.351.

Lee, R.E., 2008, Phycology: Cambridge, Cambridge University Press, 547 p.

Lei, Z., 1982, The discovery of the microflora from Lancang group and its significance: Journal of Stratigraphy, v. 12, p. 281-284.

Lewontin, R.C., 1958, Studies on heterozygosity and homeostasis II: Loss of heterosis in a constant environment: Evolution, p. 494-503.

Lewontin, R.C., 1957, The Adaptations of populations to varying environments: Cold Spring Harbor Symposia on Quantitative Biology, v. 22, p. 395-408, doi: 10.1101/SQB.1957.022.01.037. 
Li, M., Liu, P., Yin, C., Tang, F., Gao, L., and Chen, S., 2012, Acritarchs from the Baicaoping Formation (Ruyang Group) of Henan: Acta Palaeontological Sinica, v. 51, p. 76-87.

Liu, H.Y., Hao, J., and Li, Y.J., 1999, Late Precambrian stratigraphy of middleeast part of China and relatively geological evolution: Beijing, Science Press, $200 \mathrm{p}$.

Lütz-Meindl, U., and Brosch-Salomon, S., 2000, Cell wall secretion in the green alga Micrasterias: Journal of Microscopy, v. 198, p. 208-217, doi: 10.1046/ j.1365-2818.2000.00699.x.

Margulis, L., 1981, Symbiosis in Cell Evolution Life and its Environment on the Early Earth: San Francisco, Freeman and Company, 419 p.

Margulis, L., Corliss, J.O., Melkonian, M., and Chapman, D.J. (Eds.), 1989, Handbook of Protoctista: Boston, Jones and Bartlett Publishers, $914 \mathrm{p}$.

Marshall, C.P., Javaux, E.J., Knoll, A.H., and Walter, M.R., 2005, Combined micro-Fourier transform infrared (FTIR) spectroscopy and micro-Raman spectroscopy of Proterozoic acritarchs: A new approach to palaeobiology: Precambrian Research, v. 138, p. 208-224, doi: 10.1016/j.precamres. 2005.05.006.

Martí-Mus, M., and Moczydłowska, M., 2000, Internal morphology and taphonomic history of the Neoproterozoic vase-shaped microfossils from the Visings Group, Sweden: Norsk Geologisk Tidsskrift, v. 80, p. 213-228, doi: 10.1080/002919600433751.

McCartney, K., 1993, Silicoflagellates, In: Fossil Prokaryotes and Protists Lipps, J. H, (Ed.) Blackwell Scientific Publications Boston, p 143-154.

McFadden, G.I., Preisig, H.R., and Melkonian, M., 1986, Golgi apparatus activity and membrane flow during scale biogenesis in the green flagellate Scherffelia dubia (Prasinophyceae). II: Cell wall secretion and assembly: Protoplasma, v. 131, p. 174-184.

Meindl, U., 1993, Micrasterias cells as a model system for research on morphogenesis: Microbiological Reviews, v. 57, p. 415-433.

Melkonian, M., 1989, Phylum Chlorophyta: Class Chlorophyceae, in Margulis, L., Corliss, J.O., Melkonian, M., and Chapman, D.J. eds., Handbook of Protoctista, Boston, Bartlett Publishers.

Melkonian, M., Becker, B., and Becker, D., 1991, Scale formation in algae: Journal of Electron Microscopy Technique, v. 17, p. 165-178, doi: 10.1002/ jemt. 1060170205

Mendelson, C.V., 1993, Acritarchs and prasinophytes, in Lipps, J.H. ed., Fossil Prokaryotes and Protists, Boston, Blackwell Scientific Publications, p. 77-104.

Mendelson, C.V., Bauld, J.W., Horodyski, R.J., Lipps, J.H., Moore, T.B., and Schopf, J.W., 1992, Proterozoic and selected Early Cambrian microfossils and microfossil-like objects, in Schopf, J.W. and Klein, C. eds., The Proterozoic Biosphere, p. 175-243.

Meng, F., Zhou, C., Yin, L., Chen, Z., and Yuan, X., 2005, The oldest known dinoflagellates: Morphological and molecular evidence from Mesoproterozoic rocks at Yongji, Shanxi Province: Chinese Science Bulletin, v. 50, p. 1230-1234, doi: 10.1007/BF03183698.

Moczydłowska, M., 1991, Acritarch biostratigraphy of the Lower Cambrian and the Precambrian-Cambrian boundary in southeastern Poland: Fossils and Strata, v. 29, 127 p.

Moczydłowska, M., 2010, Life cycle of early Cambrian microalgae from the Skiagia-plexus acritarchs: Journal of Paleontology, v. 84, p. 216-230, doi: 10.1666/09-117R.1.

Moczydłowska, M., 2008, The Ediacaran microbiota and the survival of Snowball Earth conditions: Precambrian Research, v. 167, p. 1-15, doi: 10.1016/j.precamres.2008.06.008

Moczydłowska, M., Landing, E., Zang, W., and Palacios, T., 2011, Proterozoic phytoplankton and timing of chlorophyte algae origins: Palaeontology, v. 54, p. 721-733, doi: 10.1111/j.1475-4983.2011.01054.x.

Moczydłowska, M., and Nagovitsin, K.E., 2012, Ediacaran radiation of organicwalled microbiota recorded in the Ura Formation, Patom Uplift, Eas Siberia: Precambrian Research, v. 198, p. 1-24.

Moczydłowska, M., Schopf, J.W., and Willman, S., 2010, Micro- and nano-scale ultrastructure of cell walls in Cryogenian microfossils: revealing their biological affinity: Lethaia, v. 43, p. 129-136, doi: 10.1111/j.15023931.2009.00175.x.

Moczydłowska, M., and Willman, S., 2009, Ultrastructure of cell walls in ancient microfossils as a proxy to their biological affinities: World Summit on Ancient Microscopic Fossils, v. 173, p. 27-38, doi: 10.1016/j. precamres.2009.02.006

Moldowan, J.M., Jacobsen, S.R., Dahl, J., Al-Hajji, A., Huizingia, B.J., and Fago, F.J., 2001, Molecular fossils demonstrate Precambrian origins of dinoflagellates, in Zhuravlev, A.Y. and Riding, R. eds., The Ecology of the Cambrian Radiation, New York, Columbia University Press, p. 475-493.

Moldowan, J.M., and Talyzina, N.M., 1998, Biogeochemical evidence for dinoflagellate ancestors in the Early Cambrian: Science, v. 281, p. 1168 1170, doi: $10.1126 /$ science.281.5380.1168.

Molyneux, S.G., 2009, Acritarch (marine microphytoplankton) diversity in an Early Ordovician deep-water setting (the Skiddaw Group, northern
England): Implications for the relationship between sea-level change and phytoplankton diversity: Palaeogeography, Palaeoclimatology, Palaeoecology, v. 275, p. 59-76, doi: 10.1016/j.palaeo.2009.02.002.

Moustafa, A., Beshteri, B., Maier, U.G., and Bowler, C., 2009, Genomic footprints of a cryptic plastid endosymbiosis in diatoms: Science, v. v. 324, p $1724-1726$.

O'Kelly, C.J., 2007, The Origin and early evolution of green plants, in Falowski, P. and Knoll, A. eds., Evolution of Primary Producers in the Sea, Elsevier Academic Press, p. 287-309.

Parnell, J., Hole, M., Boyce, A.J., Spinks, S., and Bowden, S., 2012, Heavy metal, sex and granites: Crustal differentiation and bioavailability in the mid-Proterozoic: Geology, v. 40, p. 751-754, doi: 10.1130/G33116.1.

Peng, P., Sheng, G., Fu, J., and Yan, Y., 1998, Biological markers in 1.7 billion year old rock from the Tuanshanzi formation, jixian strata section, North China: Organic Geochemistry, v. 29, p. 1321-1329.

Pfiester, L.A., and Anderson, D.M., 1987, Chapter 14. Dinoflagellate life-cycles and their environmental control, in Taylor, F.J.R., ed. The Biology of Dinoflagellates. Botanical Monographs, v. v. 21 Oxford, Blackwell Scientific Publications, p 611-648.

Porter, S.M., 2006, The Proterozoic fossil record of heterotrophic eukaryotes, in Xiao, S. and Kaufman, A. eds., Neoproterozoic Geobiology and Paleobiology, Topics in Geobiology, v. 27, Springer, p. 1-21.

Porter, S.M., and Knoll, A.H., 2000, Testate amoebae in the Neoproterozoic Era: evidence from vase-shaped microfossils in the Chuar Group: Grand Canyon: Paleobiology, v. 26, p. 360-385, doi: 10.1666/0094-8373(2000) 026 < 0360:TAITNE $>2.0 . \mathrm{CO} ; 2$.

Porter, S.M., Meisterfield, R., and Knoll, A.., 2003, Vase-shaped microfossils from the Neoproterozoic Chuar Group, Grand Canyon: A classification guided by modern testate amoebae: Journal of Paleontology, v. 77, p. 409-429, doi: 10.1666/0022-3360(2003)077 < 0409:VMFTNC > 2.0.CO;2.

Raven, P.H., Evert, R.F., and Eichhorn, S.E., 2005, Biology of Plants: New York, W.H. Freeman and Company Publishers, 686 p.

Read, B.A., Kegel, J., Klute, M.J., Kuo, A., Lefebvre, S.C., Maumus, F., Mayer, C., Miller, J., Monier, A., Salamov, A., Young, J., Aguilar, M., Claverie, J.-M., Frickenhaus, S., et al., 2013, Pan genome of the phytoplankton Emiliania underpins its global distribution: Nature, v. 499, p. 209-213.

Reynolds, C.S., 2006, Ecology of phytoplankton: Cambridge, Cambridge University Press, $552 \mathrm{p}$

Rubinstein, C.V., Gerrienne, P., de la Puente, G.S., Astini, R.A., and Steemans, P., 2010, Early Middle Ordovician evidence for land plants in Argentina (eastern Gondwana): New Phytologist, v. 188, p. 365-369, doi: 10.1111/ j.1469-8137.2010.03433.x.

Runnegar, B., 1994, Proterozoic eukaryotes: evidence from biology and geology, in Early Life on Earth. Nobel Symposium, New York, Columbia University Press, p. 287-297.

Sarjeant, W.A.S., and Taylor, "Max" F. J. R., 1999, Dinoflagellates, fossil and modern: certain unresolved problems: Grana, v. 38, p. 186-192, doi: 10.1080/00173139908559227.

Schiffbauer, J.D., and Xiao, S., 2009, Novel application of focused ion beam electron microscopy (FIB-EM) in preparation and analysis of microfossil ultrastructures: A new view of complexity in early Eukaryotic organisms: PALAIOS, v. 24, p. 616-626, doi: 10.2110/palo.2009.p09-003r.

Schiffbauer, J.D., and Xiao, S., 2011, Paleobiological Applications of Focused Ion Beam Electron Microscopy (FIG-EM): An Ultrastructural Approach to the (Micro) Fossil Record, in Laflamme M., Schiffbauer, J.D., and Dornbos, S.Q., eds., Quantifying the Evolution of Early Life, Topics in Geobiology, v. 36, Springer.

Schopf, J.W., 1992, Atlas of representative Proterozoic microfossils, in Schopf, J.W. and Klein, C. eds., The Proterozoic Biosphere: A Multidisciplinary Study", Cambridge Univ. Press, Cambridge. [Links], p. 1055-1117.

Stanier, R.Y., 1970, Some aspects of the biology of cells and their possible evolutionary significance, in Knight, B.D. and Charles, H.P. eds., Organization and Control in Prokaryotic and Eukaryotic Cells, Cambridge, Cambridge University Press, p. 1-38.

Staplin, F.L., Jansonius, J., and Pocock, S.A., 1965, Evaluation of some acritarchous hystrichosphere genera: Neues Jahrbuch für Geologie und Paläontologie, Abhandlungen, v. 123, p. 167-201.

Strother, P.K., Battison, L., Brasier, M.D., and Wellman, C.H., 2011, Earth/'s earliest non-marine eukaryotes: Nature, v. 473, p. 505-509, doi: 10.1038/ nature09943.

Suda, S., Watanabe, M.M., and Inouye, I., 2004, Electron microscopy of sexual reproduction in Nephroselmis olivacea (Prasinophyceae, Chlorophyta): Phycological Research, v. 52, p. 273-283, doi: 10.1111/j.1440-183.2004. 00346.x.

Summons, R.E., Thomas, J., Maxwell, J.R., and Boreham, C.J., 1992, Secular and environmental constraints on the occurrence of dinosterane in sediments: Geochimica et Cosmochimica Acta, v. 56, p. 2437-2444, doi: 10.1016/0016-7037(92)90200-3. 
Talyzina, N.M., and Moczydłowska, M., 2000, Morphological and ultrastructural studies of some acritarchs from the Lower Cambrian Lükati Formation, Estonia: Review of Palaeobotany and Palynology, v. 112, p. 1-21, doi: 10.1016/S0034-6667(00)00032-4.

Tappan, H., 1980, The Paleobiology of Plant Protists: San Francisco, WH Freeman, $1028 \mathrm{p}$.

Traverse, A., 2007, Paleopalynology: Topics in Geobiology, v. 28, Springer Verlag, v. 28, 813 p.

Turmel, M., Brouard, J.-S., Gagnon, C., Otis, C., and Lemieux, C., 2008, Deep division in the Chlorophyceae (Chlorophyta) revealed by chloroplast phylogenetic analyses: Journal of Phycology, v. 44, p. 739-750, doi: 10.1111/ j.1529-8817.2008.00510.x.

Turmel, M., Otis, C., and Lemieux, C., 2002, The complete mitochondrial DNA sequence of Mesostigma viride identifies this green alga as the earliest green plant divergence and predicts a highly compact mitochondrial genome in the ancestor of all green plants: Molecular Biology and Evolution, v. 19, p. 24-38.

Vajda, V., and McLoughlin, S., 2004, Fungal proliferation at the CretaceousTertiary Boundary: Science, v. 303, p. 1489-1489, doi: 10.1126/science. 1093807.

van den Hoek, C., Mann, D.G., and Jahns, H.M., 1995, Algae: An introduction to phycology: Cambridge, Cambridge University Press, $623 \mathrm{p}$.

Vidal, G., 1988, A palynological preparation method: Palynology, v. 12, p. 215-220, doi: 10.1080/01916122.1988.9989345.

Volkman, J.K., 2005, Sterols and other triterpenoids: source specificity and evolution of biosynthetic pathways: Organic Geochemistry, v. 36, p 139-159.

Volkman, J.K., Barrett, S.M., Blackburn, S.I., Mansour, M.P., Sikes, E.L., and Gelin, F., 1998, Microalgal biomarkers: A review of recent research developments: Organic Geochemistry, v. 29, p. 1163-1179, doi: 10.1016/ S0146-6380(98)00062-X.

Volkman, J.K., Barrett, S.M., Dunstan, G.A., and Jeffrey, S.W., 1993 , Geochemical significance of the occurrence of dinosterol and other 4-methyl sterols in a marine diatom: Organic Geochemistry, v. 20, p. 7-15, doi: 10.1016/0146-6380(93)90076-N.

Wacey, D., Menon, S., Green, L., Gerstmann, D., Kong, C., Mcloughlin, N., Saunders, M., and Brasier, M., 2012, Taphonomy of very ancient microfossils from the $\sim 3400$ Ma Strelley Pool Formation and 1900 Ma Gunflin Formation: New insights using a focused ion beam: Precambrian Research, v. 220-221, p. 234-250, doi: 10.1016/j.precamres.2012.08.005.

Webster, J., and Weber, R.W.S., 2007, Introduction to Fungi: Cambridge University Press, $841 \mathrm{p}$.

Weiss, T.L., Roth, R., Goodson, C., Vitha, S., Black, I., Azadi, P., Rusch, J., Holzenburg, A., Devarenne, T.P., and Goodenough, U., 2012, Colony organization in the green alga Botryococcus braunii (Race B) is specified by a complex extracellular matrix: Eukaryotic Cell, v. 11, p. 1424-1440, doi: 10.1128/EC.00184-12.

Wellman, C.H., Osterloff, P.L., and Mohiuddin, U., 2003, Fragments of the earliest land plants: Nature, v. 425, p. 282-285, doi: 10.1038/nature01884.

Wicander, R., 2007, Acritarchs and Prasinophyte Phycoma: Lisbon, Portugal, Acritarch Subcommisssion, $15 \mathrm{p}$.
Wicander, R., 2002, Acritarchs: Proterozoic and Paleozoic enigmatic organicwalled microfossils, in International Symposium on Optical Science and Technology, International Society for Optics and Photonics, p. 331-340.

Willman, S., 2009, Morphology and wall ultrastructure of leiosphaeric and acanthomorphic acritarchs from the Ediacaran of Australia: Geobiology, v. v.7, p 8-20.

Willman, S., and Moczydłowska, M., 2007, Wall ultrastructure of an Ediacaran acritarch from the Officer Basin, Australia: Lethaia, v. 40, p. 111-123, doi: 10.1111/j.1502-3931.2007.00023.x.

Xiao, S., Knoll, A.H., Kaufman, A.J., Yin, L., and Zhang, Y., 1997, Neoproterozoic fossils in Mesoproterozoic rocks? Chemostratigraphic resolution of a biostratigraphic conundrum from the North China Platform: Precambrian Research, v. 84, p. 197-220, doi: 10.1016/S0301-9268(97)00029-6.

Xiao, S., Zhang, Y., and Knoll, A.H., 1998, Three-dimensional preservation of algae and animal embryos in a Neoproterozoic phosphorite: Nature, v. 391, p. 553-558, doi: 10.1038/35318.

Xing, Y., 1982, Microflora of the Sinian System and Lower Cambrian near Kunming, Yunnan and its stratigraphic significance: Acta Geological Sinica, v. 56, p. 42-49.

Xing, Y., and Liu, K., 1973, On Sinian microflora in Yenliao region of China and its geographic significance: Acta Geologica Sinica, v. 1, p. 1-64.

Yan, Y., and Zhu, S., 1992, Discovery of acanthomorphic acritarchs from the Baicaoping Formation in Yongii, Shanxi and its geological significance: Acta Micropalaeontologica Sinica, v. 9, p. 267-282.

Yin, L., 1997, Acanthomorphic acritarchs from Meso-Neoproterozoic shales of the Ruyang Group, Shanxi, China: Festschrift for Helen Tappan and Alfred R. Loeblich Jr., 98, p. 15-25, doi: 10.1016/S0034-6667(97)00022-5.

Yin, L., and Yuan, X., 2007, Radiation of Meso-Neoproterozoic and Early Cambrian protists inferred from the microfossil record of China: From Snowball Earth to the Cambrian bioradiation: calibration of EdiacaranCambrian history in South China, v. 254, p. 350-361, doi: 10.1016/j. palaeo.2007.03.028.

Yin, L., and Yuan, X., 2003. Review of the microfossil assemblage from the Late Mesoproterozoic Ruyang Group in Shanxi: China, Acta Micropalaeontologica Sinica v. 20, p 39-46.

Yin, L., Yuan, X., Meng, F., and Hu, J., 2005, Protists of the Upper Mesoproterozoic Ruyang Group in Shanxi Province, China: Precambrian Research, v. 141, p. 49-66, doi: 10.1016/j.precamres.2005.08.001.

Yoon, H.S., Hackett, J.D., Ciniglia, C., Pinto, G., and Bhattacharya, D., 2004, A molecular timeline for the origin of photosynthetic eukaryotes: Molecular Biology and Evolution, v. 21, p. 809-818, doi: 10.1093/molbev/msh075.

Zhao, T.-P., Zhou, M.-F., Zhai, M., and Xia, B., 2002, Paleoproterozoic rift-related volcanism of the Xiong'er Group, North China Craton: Implications for the breakup of Columbia: International Geology Review, v. 44 p. 336-351, doi: 10.2747/0020-6814.44.4.336.

Accepted 18 March 2014 